\title{
Vesalius Revised. His Annotations to the 1555 Fabrica
}

\author{
VIVIAN NUTTON* \\ 225, Sandpit Lane, St Albans AL4 0BT, UK
}

\begin{abstract}
The De humani corporis fabrica [The Fabric of the Human Body], Basle, 1543, of Andreas Vesalius is deservedly famous as the first modern book of anatomy. A second edition was published in Basle in 1555, but little is known of Vesalius' activities after that date. This article discusses a recent find: Vesalius' own copy of the 1555 edition, heavily annotated in preparation for a never published third edition. Vesalius made hundreds of changes to the second edition, the great majority being stylistic, altering the Latin words but not the overall meaning. There are also changes to the plates to give greater clarity or to correct mistakes by the original block-cutter. There is little new anatomical material, although Vesalius continued to meditate about what he had earlier discovered. He shows no sign of being acquainted with the findings of others, like Colombo or Falloppia, that were published after he had moved his residence from Brussels to Spain in summer 1559, perhaps leaving this volume behind. The number of annotations shows Vesalius' passionate concern not only for accuracy but also for the most effective way of proclaiming his new anatomical message.
\end{abstract}

Keywords: Anatomy, Vesalius, Printing, Illustration, Humanism, Latin

Andreas Vesalius of Brussels (1514-64) was regarded, even in his lifetime, as the creator of modern anatomy. ${ }^{1}$ Although trained in Louvain and Paris in the classical tradition of medicine that looked back to the Greek physician Galen of Pergamum (129-ca. 216), he

* Email address for correspondence: ucgavnu@ucl.ac.uk

My thanks above all go to Gerard Vogrincic, who invited me to edit the annotations and who provided me with excellent photographs as well as an opportunity to see them in person. Dan Garrison, Malcolm Hast, Sachiko Kusukawa, Claudia Stein and Andrew Wear read drafts of this article and gave me details of their own work in progress. Monica Azzolini and Iain Donaldson answered questions about the Edinburgh copies of the Fabrica. Ueli Dill, Martin Steinmann and Ian Maclean provided helpful advice about Basle book production, and Chris Coppens was a useful guide to matters Belgian. Anonymous readers of this journal raised valuable queries which have clarified my argument. Randall Packard kindly sent me images of the Johns Hopkins copy of the Fabrica for comparison. Gabriella Karger generously arranged for me to attend a meeting to discuss the forthcoming edition of the Garrison and Hast translation, and her production staff, Herbert Waeckerlin and Erich Geschwind, advised about illustrations. Much of this was written in the final days of the Wellcome Trust Centre for the History of Medicine, an inimitable institution sadly destroyed. Roger Cooter and Michael Laycock of the former editorial team of this journal gave considerable encouragement. My wife, as always, commented critically on my drafts. Any errors and misperceptions that remain are my own.

1 Vivian Nutton, ‘An Early Reader of Vesalius', Fabrica Vesalius, 3 (1998), 73-4; Moritz Roth, Andreas Vesalius Bruxellensis (Berlin: Georg Reimer, 1892), 244-63, is a useful compendium of reactions, both for and against. Cynthia Klestinec, Theaters of Anatomy. Students, Teachers and Traditions of Dissection in Renaissance Venice 
broke decisively with his predecessors when in 1543 he published his monumental De humani corporis fabrica [The Fabric of the Human Body]. ${ }^{2}$ It was a revolutionary book. ${ }^{3}$ It exploited the power of the printing press, as well as the skill of all those involved in its production, typesetters, artists and block-cutters alike, to create and reproduce images of the human body that were larger and more life-like than any that had gone before. Vesalius established a dialogue between the verbal and the visual, constantly using his images to explain his text, and vice versa. ${ }^{4}$ It was a tour-de-force in every way, fit to be dedicated to the most powerful monarch of the day, Charles V, the Holy Roman Emperor.

It was also a book that provoked controversy because of its message: human anatomy, Vesalius averred, could, and should, be studied only on the basis of human dissection. This blunt affirmation not only revealed Vesalius as a brash young man in a hurry, too little respectful of his masters, but also threw down a challenge to many who believed, with good reason, that their own way of dissecting, describing and interpreting the human body was itself a mark of modernity, a true renaissance of past glories. ${ }^{5}$ In following the anatomical teachings of Galen that had become largely available in Western Europe only in the late fifteenth century, and arguably only after the publication of up-to-date Latin versions from 1528 onwards, these anatomists believed that they had overthrown the defective anatomical writings and practices of the previous two centuries. Galen's rediscovered work was more precise, his skill with the knife more patent and his exposition more extensive than anything that had been written for thirteen centuries. ${ }^{6}$ That his description of the body was based largely on animal dissection did not present an obstacle to those who knew of his experiences as a surgeon in Pergamum and Rome, which, so they argued, must have informed his anatomical treatises in some way. He had made errors, but these were few and far between. Anatomy came into fashion almost overnight, and not only

(Baltimore: Johns Hopkins University Press, 2011), 1-4, rightly points out that Vesalius' injunctions were followed neither immediately nor, even in Padua, consistently.

${ }^{2}$ C. Donald O'Malley, Andreas Vesalius of Brussels, 1514-1564 (Berkeley: University of California Press, 1964), remains the most detailed and accessible biography of Vesalius. There is much of value in the introduction to André Vésale, Résumé des ses livres sur la fabrique du corps humain, Andreae Vesalii Bruxellensis suorum de humani corpis fabrica librorum epitome. Texte et traduction par Jacqueline Vons. Introduction, notes et commentaire par Jacqueline Vons et Stéphane Velut (Paris: Les Belles Lettres, 2008). The same French team has embarked on a French translation of the Fabrica, the first part of which is scheduled to appear in 2012.

${ }^{3}$ Andreas Vesalius, De Humani Corporis Fabrica (Basle: J. Oporinus, 1543). A complete English version of this edition was made by William F. Richardson and John B. Carman, Andreas Vesalius, On the Fabric of the Human Body, 5 vols (Novato, CA: Norman Publishing, 1998-2009). A translation of the 1543 edition along with the changes introduced in the second edition has been prepared by Daniel H. Garrison and Malcolm H. Hast, Andreas Vesalius, The Fabric of the Human Body (2003). An early draft of Book I is available on line at http://vesalius.northwestern.edu; the complete version will be published by S. Karger at Basle in 2014.

${ }^{4}$ Sachiko Kusukawa, 'The uses of pictures in the formation of learned knowledge: the cases of Leonhard Fuchs and Andreas Vesalius', in Sachiko Kusukawa and Ian Maclean (eds), Transmitting Knowledge: Words, Images, and Instruments in Early Modern Europe (Oxford: Oxford University Press, 2006), 73-96; Picturing the Book of Nature: Image, Text and Argument in Sixteenth century Human Anatomy and Medical Botany (Chicago: University of Chicago Press, 2011). Relevant also is Andrea Carlino, Books of the Body: Anatomical Ritual and Renaissance Learning, John Tedeschi and Anne C. Tedeschi (trans.) (Chicago: University of Chicago Press, 1999).

${ }^{5}$ Andrew Cunningham, The Anatomical Renaissance. The Resurrection of the Anatomical Projects of the Ancients (Aldershot: Scolar Press, 1997); Roger K. French, Dissection and Vivisection in the European Renaissance (Aldershot: Ashgate, 1999); Katharine Park, Secrets of Women: Gender, Generation, and the Origins of Human Dissection (New York: Zone, 2006); Klestinec, Theaters.

6 Julius Rocca, Anatomy' and Armelle Debru, 'Physiology', in R. J. Hankinson (ed.), The Cambridge Companion to Galen (Cambridge: Cambridge University Press, 2008), 242-62, 263-82, provide a convenient overview of Galen's work, very little of which was known directly until the Western Middle Ages. 
among medical men. ${ }^{7}$ The new Galenism triumphed in the universities, and those who opposed the doctrines of Galen were derided and even dismissed from their posts. That Vesalius, trained as a Galenist and himself an editor of Galen's texts, should criticise his predecessor so much and apparently so unfairly was thus viewed by some as the utmost impiety. But others, perhaps the majority of Vesalius' readers, accepted the new message as a continuation of the empirical and experimental methodology that Galen had advocated but been unable to put into practice. In Germany, Philip Melanchthon quickly adopted it as the basis for the anatomical sections of his revised treatise De anima, which was required reading among Lutheran intellectuals. ${ }^{8}$ Vesalius' anatomical plates were swiftly copied around Europe, and authors such as Valverde gained a reputation through their publication of Vesalius' ideas in a more accessible form. ${ }^{9}$

Vesalius himself played little direct part in the teaching of anatomy after the publication of the Fabrica in 1543. Within weeks he was appointed physician to Emperor Charles V and henceforth, apart from a brief return to Italy, when he performed dissections at Padua and Pisa, his life was spent in court circles in the Netherlands or later in Spain. He had no immediate intention of returning to academic life, for, as he wrote only a few years later, in 1546, he burnt 'everything', including the notes he had made over the years and inscribed in the margins of his copies of Galen's printed books. His friends had tried to dissuade him from this rash course, which he came to regret at least as far as his non-Galenic books were concerned, but one can see why a return to his home city of Brussels, allied to well-paid service with the greatest monarch of the age, had its attractions. ${ }^{10}$

He retained his interest in dissection, but, apart from autopsies and occasional surgery, his opportunities to ply the knife were restricted. He does, however, appear to have kept himself informed about the publications of others, both those that added new discoveries and those that simply took over his writings, and he clearly spent a great deal of time making changes to what he had written earlier. His publisher, Oporinus, was already announcing a new edition of the Fabrica in 1552, but it is not clear whether this was the slightly altered revision that still bears the date of 1543 or, more likely, the much greater re-edition that appeared at Basle in $1555 .{ }^{11}$ In the latter Vesalius made many alterations, improving both text and illustrations, removing matter that now appeared out-dated and

7 Vivian Nutton, 'André Vésale et l'anatomie parisienne', Cahiers de l'Association Internationale des Études Françaises, 55 (2003), 239-49.

${ }^{8}$ Vivian Nutton, 'Wittenberg anatomy', in Ole P. Grell and Andrew Cunningham (eds), Medicine and the Reformation (London: Routledge, 1993), 11-32; Jürgen Helm, 'Religion and medicine: anatomical education at Wittenberg and Ingolstadt', in Jürgen Helm and Annette Winkelmann (eds), Religious Confessions and the Sciences in the Sixteenth Century (Leiden: Brill, 2001), 51-68.

${ }^{9}$ Elly Cockx-Indestege, Andreas Vesalius. A Belgian Census (Brussels: Royal Library, 1994), provides a convenient guide to the copies. Cynthia Klestinec, 'Juan Valverde de (H)Amusco and print culture. The editorial apparatus in vernacular anatomical texts', in Albert Schirrmeister (ed.), Zergliederungen - Anatomie und Wahrnehmung in der frühen Neuzeit. Zeitsprünge, Forschungen zur frühen Neuzeit, 9, 1-2 (Frankfurt: Vittorio Klostermann, 2005), 78-94, defends Valverde. Vesalius had little time for the Spaniard, whose reputation as an anatomist he considered unjustified. In general on the notion of plagiarism, see Pamela O. Long, Openness, Secrecy, Authorship: Technical Arts and the Culture of Knowledge from Antiquity to the Renaissance (Baltimore: Johns Hopkins University Press, 2001).

${ }^{10}$ Andreas Vesalius, Epistola rationem modumque propinandi radicis Chynae decocti (Basle: J. Oporinus, 1546), 195; O’Malley, op. cit. (note 2), 223. Vesalius had long had family connections with the Brussels court through his father, a royal apothecary.

${ }^{11}$ For the variant edition, see Michael Horowitz and Jack Collins, 'A Census of Copies of the First Edition of Andreas Vesalius' De humani corporis fabrica (1543), with a Note on the Recently Discovered Variant Issue', Journal of the History of Medicine and Allied Sciences, 39 (1984) 198-221. For the financial crisis of 1552, 
responding to criticisms. O'Malley in his description of the contents of this revision, although understating the extent of the changes introduced, most of them stylistic, was right to emphasise that very few involved the addition of new material deriving from Vesalius' own recent anatomies. Rather, it seems that many were the result of Vesalius' continued meditation on work he had done much earlier or on discoveries recounted to him by others. ${ }^{12}$

Very little is known of Vesalius' activities after 1555. He assisted in the treatment, and autopsy, of a few distinguished patients such as Ferrante Gonzaga of Mantua and Henri II of France, but these were both exceptional cases. ${ }^{13}$ His only publication, his Anatomicarum Gabrielis Falloppii observationum examen, appeared in Venice with a preface dated to 24 May 1564, although the author's preface is dated 'from the royal court in Madrid, 17 December, 1561'. Spain, where he moved with his wife in summer 1559, was an even less favourable environment than Brussels. ${ }^{14}$ He complained that, compared with the happy life he had once enjoyed at Padua, he saw little possibility of performing a dissection and indeed that he could not easily obtain a skull. ${ }^{15}$ Many physicians there openly supported Galen against Vesalius and some courtiers were apparently hostile to him. There were rumours that he had in some way been involved in the dissection of a living human body and that his decision to visit the Holy Land in 1564 was a form of penance. ${ }^{16}$ More strongly based is the report by a Venetian that Vesalius was planning to return to Padua as a senior professor of medicine once his pilgrimage was over. However, before he could do so, he died suddenly on an island in the Adriatic. ${ }^{17}$

\section{Vesalius' Copy of the 1555 Fabrica}

Recently, a new and surprising source of information on the activities of Vesalius during his last years has been identified, a copy of the 1555 edition of the Fabrica owned and

see Martin Steinmann, 'Johannes Oporinus. Ein Basler Buchdrucker um die Mitte des 16. Jahrhunderts', Basler Beiträge zur Geschichtswissenschaft, 105 (1967), 87-8.

12 O'Malley, op. cit. (note 2), 269-82, is the only detailed survey of the changes, but useful remarks can be found also in Nancy G. Siraisi, Medicine and the Italian Universities (Leiden: Brill, 2001), especially in chs. 12 and 13. The forthcoming Karger edition will include translations of all the substantial changes. For surviving copies, see Stephen N. Joffe, 'A Census of the Edition of 1555 of Andreas Vesalius', International Archives of Medicine, 2 (2009), 26.

13 O'Malley, ibid., 283-314, covers his last years, but does not mention Gonzaga. Vesalius attended him in Brussels in November 1557, and assisted in his autopsy, see David S. Chambers, 'A Mantuan in London in 1557: Further Research on Annibale Litolfi', in Edward Chaney and Peter Mack (eds), England and the Continental Renaissance. Essays in Honour of J. B. Trapp (Woodbridge: The Boydell Press, 1990), 73-108, at 96.

14 The court of Charles V and, from 1556 onwards, his successor Philip II stayed in Brussels until mid-1559 to deal with both the French wars and recalcitrant Netherlanders. The letter of Clusius, Roth, op. cit. (note 1), 243, implies that Vesalius had left by August 1559.

15 Andreas Vesalius, Anatomicarum Gabrielis Falloppii observationum examen (Venice: F. de' Franceschi, 1564), 171.

${ }^{16}$ Particularly if there were already rumours about the reasons for the pilgrimage. Andreas Dudith strongly doubted the story circulating in Padua in 1582, and ultimately coming from Paré's De generatione (1573), that it was to atone for an accidental vivisection, see L. Scholzius, Consiliorum et epistolarum medicinalium Ioh. Cratonis a Kraftheim...et aliorum excellentissimorum medicorum ac philosophorum, III (Frankfurt: Wechel, 1592), 301, the earliest printed source to mention Vesalius by name, although his identity is already clear from Paré.

${ }^{17}$ O’Malley, op. cit. (note 2), 306-7; Roth, op. cit. (note 1), 278. 


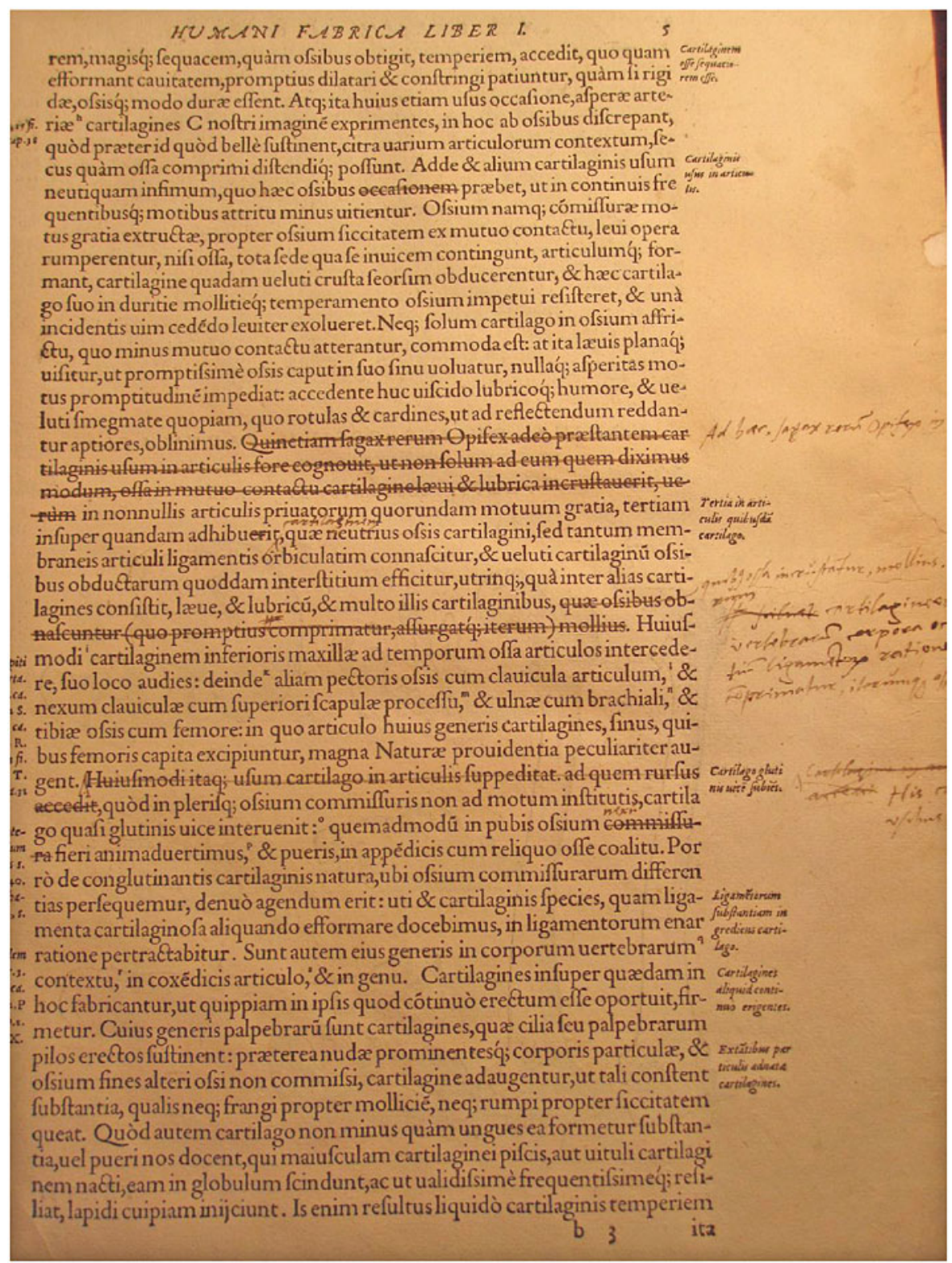

Figure 1: Andreas Vesalius, De humani corporis fabrica (Basle: J. Oporinus, 1555), p. 5. Vesalius' corrections are inserted between the lines and in the margin.

heavily annotated by Vesalius himself (figure 1). The volume, which was sold in 2007 in Hamburg by a German owner, is now deposited on loan at the Thomas Fisher Rare Book Library of the University of Toronto.

The book itself is in reasonably good condition, although the opening pages show a variety of signs of damage and it lacks pp. 669-72, which formed the inner leaf of 
gathering mm. ${ }^{18}$ The final gatherings, Bb-Ee, containing the Errata page, the index, the list of gatherings, the colophon and the printer's mark, are also missing, an important omission that will be discussed later. The whole volume was rebound in vellum at a later date, perhaps in the last century. Whether it was then that new blank sheets were inserted for protection at the beginning and end and the pages trimmed to fit the new size is unclear. ${ }^{19}$ As a result of this cropping, comments made in the outer margins frequently lack two or three letters on each line, thus adding to the complications of transcription. The rebinding has also meant that several comments made on the inner margins are almost illegible because of the tightness of the binding. However, many of the gaps can be filled either because Vesalius himself wrote out the comment in a more legible form elsewhere on the page or because he was repeating words already in the printed text. But where a top or bottom line has been lost, eg. pp. 516 and 805, it is impossible to restore what was once there. An added complication is that Vesalius' habit of adding corrections to his corrections, and at times the vigour of his deletions, make some transcriptions difficult. The ink has also faded in parts, particularly the paler and reddish ink used in some of the later annotations, and it is not always easy to see where a deletion begins or ends, or where a word or phrase should be transferred. ${ }^{20}$

The history of the book before 2007 is hard to trace. A tiny handful of annotations may belong to a later (seventeenth century?) owner, who comments at one point, in the margin of p. 283, on the changes made in a Lugdunensis li(ber), presumably the Lyons edition of 1552. ${ }^{21}$ There are traces of writing on the upper part of the frontispiece and on the back cover, but nothing that can be linked securely to the annotator. At some point the volume belonged to an institution, for the base of the spine is impressed with a circle, $34 \mathrm{~mm}$ in diameter, and bears traces of the thin paper strips that once held a circle with, presumably, a shelf mark. The author's name and the title are stamped into the spine as A. WESALE DE HUMANI CORPORIS FABRICA, a curious combination of languages that suggests that the book was at one point in a Dutch/Flemish speaking area. ${ }^{22}$

\section{Authenticity}

Although there are no signatures to identify the annotator, there can be no doubt that he was Vesalius. ${ }^{23}$ Although he used three slightly different styles of writing, all exhibit many characteristics which closely resemble those in the surviving letters of Vesalius, especially those now preserved in the Waller Collection at Uppsala, Ms. benl. 00758 and 00759.

\footnotetext{
18 The fact that the 1555 Errata contain corrections to pp. 669 and 672 suggests that these pages were lost some time later, perhaps during binding.

19 The cropping certainly took place after a later owner had made his comment on p. 283 , for this is also cropped.

${ }^{20}$ My transcriptions were initially made from excellent photographs provided by the owner. A later inspection allowed me to check doubtful passages, particularly where the ink had become faint.

${ }^{21}$ Multa hic Lugdunensis li(ber) immutauit quae ea ratione (word cropped and illegible and replaced by another illegible word) ibi tradunt, a reference to the Lyons edition (Lyons: J. Tornaesius, 1552), 83, where the chapter is numbered 10. The comment does not fit the Leiden edition of the Opera omnia (J. du Vivié and J and H. Verbeek, 1725), Vol. I, 195, which reprints the 1555 text.

22 Several of the early printings of Latin texts by Vesalius call him Wesalius, as does John Caius, his former flatmate, in his notes on Galen in Eton College, sig. Fc.2.6, but the French spelling is with a 'V'. The stamped lettering is not as elegant as one might have expected.

${ }^{23}$ A flamboyant ' $A$ ' on the frontispiece could well be the initial letter of an otherwise lost Andreas, but the letter does not entirely correspond to the initial 'A' of the ownership mark in two other books from Vesalius' library (O’Malley, op. cit. (note 2), plate 10) or to the signature in known letters.
} 
The differences between the three styles largely depend on the place on the page where the annotator was writing. Between the lines he uses a smaller and squarer hand than in the margins, and the latest notes appear to have been written in a more flowing hand and in much paler ink. The handwriting, however, differs slightly from that on the annotated copy of Vesalius' revision of Guinther's Institutiones anatomicae of 1538, formerly in the Norman Collection and sold at Christie's New York in 1998. That discrepancy, however, can be easily explained by the almost twenty years that separate the two sets of notes and, as will be seen, the idiosyncratic method of the annotator in both instances is identical. $^{24}$

One passage at the end of the volume also points unequivocally to Vesalius. On p. 654, 5 lines from the end, figure 2, Vesalius had not altered in 1555 his comment that it was still possible for him to observe the Jewish practice of circumcision (adhuc cernimus). In his correction this possibility is now relegated to the past: 'as I saw more than once in Venice and Padua (non semel Venetiis et Patauii vidi)'. A further reminiscence of Northern Italy may occur even later, p. 721, bottom, where the tonsils are compared to stakes driven into the shore to which a boat can be tied up (uti $<$ et $>$ palis qui religandae nauis gratia littori infiguntur), a comparison unfamiliar to Brussels and certainly to landlocked Madrid, but obvious to those living around the Venetian lagoons.

\section{The Annotations}

There are well over a thousand annotations and corrections of various sorts - deletions, additions, transpositions of words and marginal notes (sometimes merely indicated by a sign), as well as hundreds of changes of wording. Particularly in the first three quarters of the volume, few pages are without some correction, and several contain three or four. Other annotators, including some readers of the Fabrica, may have filled the margins of their books with comments but none paid such attention to the actual wording. ${ }^{25}$ The closest parallel to the sheer abundance and the variety of these Vesalian corrections can be found in the Norman copy of his revision of Guinther's Institutiones anatomicae. In the words of its Christie's cataloguer:

While a copy of the first edition was still in sheets, unbound, Vesalius entered further corrections and annotations in preparation for a new edition. His changes not only rectify typographical errors and mistakes in layout (e.g. the incorrect placement of shoulder notes), but they also introduce significant modifications to the text, including revisions, deletions, and additions. In Book IV entire paragraphs of text are cancelled (M1r, M3r-v), and in Book II instructions are given for the placement of a figure (F8v). ${ }^{26}$

\footnotetext{
24 Gerard Vogringic provided me with photographs of the Waller letters, as well as with the detailed comparisons of the hand in both notes and letter that allowed him to identify the annotator. For the Norman notes, see the image in the sale catalogue, Christie's New York, Sale 8854, The Haskell F. Norman Library of Science and Medicine, 18 March 1998, lot 211. But the single image in the catalogue may not give a full view of the range of scripts used by Vesalius in the volume. For other scripts, see also Hossam Elkhadem, Andreas Vesalius. Experiment en Onderwijs in de Anatomie tijdens de 16e Eeuw (Brussels: Koninklijke Bibliotheek Albert I, 1993), 18-23, 27.

25 The owner of the copy of the 1543 Fabrica, now in the Welch Library at Johns Hopkins University, transcribed all the changes in the 1555 edition, but his enthusiam flagged after Book I and he gave up entirely by Book III. Thomas Lorkyn (1528-1591), Regius Professor of Physics at Cambridge, also wrote copious notes in his copy, Cambridge University Library, sig. $N^{*} .1 .1$ (A), inserting many cross-references and summaries, and using it as a repository for his own anatomical findings, but he plays little or no attention to the language. Lorkyn's copy is discussed by Kusukawa, Picturing the Book, op. cit. (note 4), in her epilogue, where, 291, n. 10, she also records another much less heavily annotated copy.

26 Sale Catalogue, op. cit. (note 24).
} 


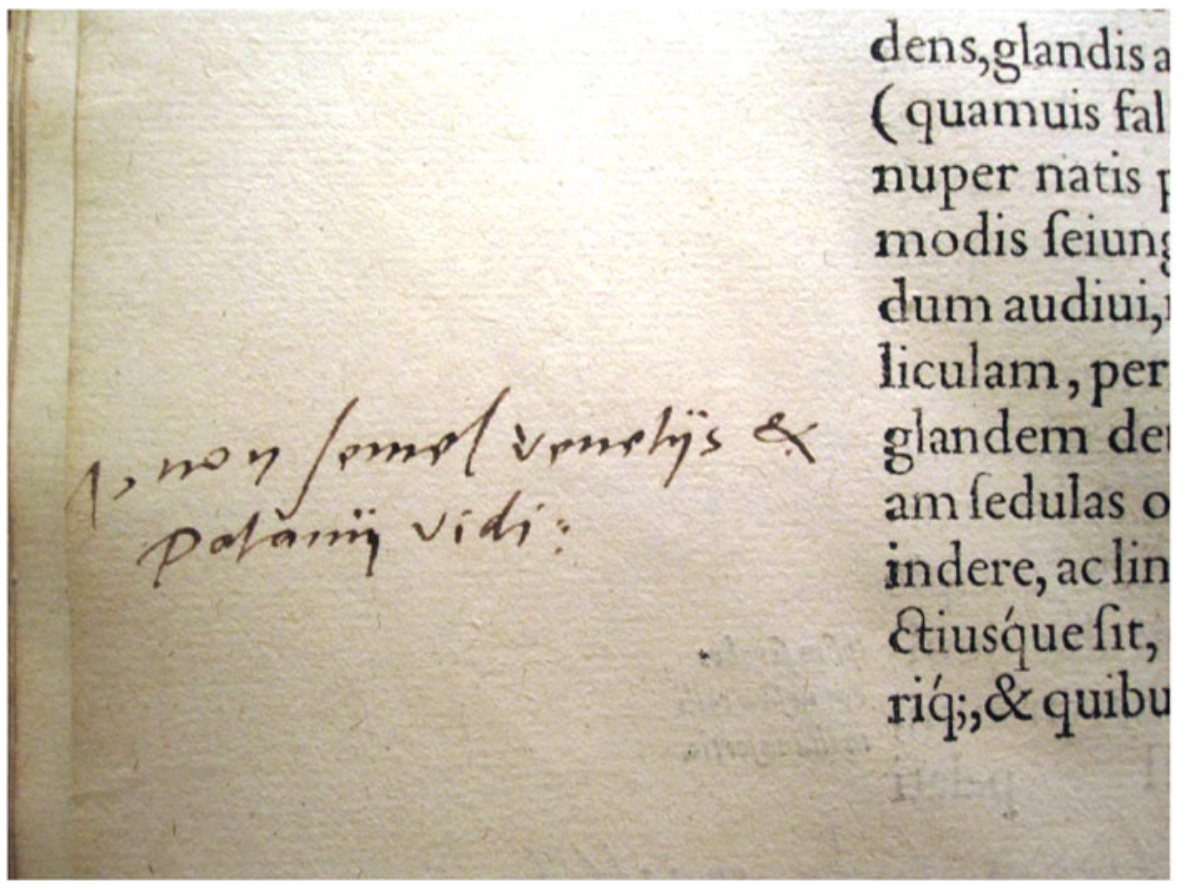

Figure 2: De humani corporis fabrica, p. 654. Vesalius alters his comment that it was still possible for him to observe the Jewish practice of circumcision (adhuc cernimus) to: 'as I saw more than once in Venice and Padua (non semel Venetiis et Patauii vidi)'.

Vesalius also made similar changes in his preparations for the 1555 revision of the Fabrica, where they are both more numerous and more trivial than O'Malley's account implies, and cannot always be detected in Garrison's English version because they involve alterations to the style of expression, not to the meaning of the Latin. ${ }^{27}$ Besides, only the author would have devoted such effort to making the stylistic changes that appear throughout this recently located volume, or would have had the courage to eliminate some of the personal details that are found in the second edition.

The annotations were intended for publication, if not from the very start, at least at some point soon afterwards. Many of the more complicated notes are rewritten more clearly in the margin or at the head or foot of the page. Vesalius also uses many printers' marks to show deletions, additions or the run-ons from one line to the next of a note, and, most striking of all, he indicates several times by the use of a line and arrow where a wrongly placed marginal heading should go. His redrawing of plates, along with their explanations, and his clarification of letters obscured by excessive shading can be understood only as instructions to a future printer and block-cutter. Finally, many of the verbal changes presuppose a continuing readership, addressed directly by Vesalius in the second person, that is expected to be eager to carry out a dissection in the manner prescribed in the book. Vesalius is writing a textbook, not an aide-mémoire.

27 O’Malley, op. cit. (note 2), 269-82. See also Garrison and Hast, op. cit. (note 3). 


\section{The Errata of 1555}

The second edition of the Fabrica, although anatomically superior to that of 1543, was less accurately printed than its predecessor, almost certainly because Vesalius was not himself then in Basle to supervise every stage of its production. Oporinus had to add at sig. $\mathrm{Bb}$ 1r, a long list of corrections supplied by the author, ending with the assurance that 'the careful reader will easily discover the rest for himself'. All these passages are corrected by Vesalius in his notes, but not always in the way indicated in the Errata. Sometimes he prefers a slightly different word:

p. 37,4 oculos munire Errata] praemunire

p. $469 \mathrm{mg}$. incessus Errata] series.

But sometimes more is involved. ${ }^{28}$ On p. 259, 29, the Errata advise the simple change of the nonsensical extremam ('furthest') to externam ('outside') but in the notes the words are altered to a more expansive phrase: ossa externa sede ambientium ('embracing the bones on their outside'). On p. 62, 2 from the end, the clearly wrong hic ('here') is replaced in the Errata by his ('these'), but this is altered by Vesalius in his notes to the more elegant nuper dictis ('just mentioned'), which then entails the replacement in the following line of nuper dictae by the slightly different formulation of the same concept, commemoratae modo.

Sometimes Vesalius' uncertainties can be seen even as he makes the correction. On p. 63, 13 from the end, a sentence was left out in the 1555 edition, and was eventually corrected to what is given in the Errata, but before then Vesalius had first inserted a clause emphasising that the smoothness of the frontal bone of the skull had been 'set there by Nature' (et [then replaced by ac] a Natura instituta), and then deleted it. In the long addition on p. 129, 9, Vesalius replaces digitos extendentibus, '(tendons) extending the fingers' with the teleological quorum beneficio digiti extenduntur, 'by whose beneficial action the fingers are extended', and transfers the clause to the end of the sentence to refer also to the toes. However, he does not then add the sentence in the Errata that claims that these tendons can become almost like bones through being contracted for a long time. ${ }^{29}$ In short, there is a puzzling lack of fit between the notes and the Errata. Many of the obvious corrections made in the notes do not appear in the Errata, and, vice versa, the formulations in the Errata are not always followed exactly in the notes. Indeed, for the most part, the changes in the notes indicate corrections made by a reader while going carefully through the book rather than copying suggestions directly from the page of Errata.

A consideration of Oporinus' normal practices in his dealings with authors together with a close examination of the physical make up of this copy reveals an unexpected solution: these were the sheets originally sent by Oporinus in Basle to Vesalius in Brussels for his attention before publication and later used for some years by Vesalius as the basis for a potential third edition.

According to Martin Steinmann, if an author was not resident in Basle, then the proof copy of the text was read by Oporinus and his staff before it was printed and sent, often in small sections, to the author. He would then send a list of Errata back to Basle, which

\footnotetext{
${ }^{28}$ References are given by page and, usually, line. To aid finding a word in the large page, some lines are indicated by their distance from the foot of the page. The following symbols are used in the transcriptions: $<>$ marks an addition, \{\} a deletion, (...) the replacement of letters lost in the binding, / a line-break.

${ }^{29}$ On p. 452, 30 his initial formulation is altered by replacing 'Galen' with 'him', and then the sentence is rewritten in a slightly shorter form that still does not agree in wording (although it does in content) with what is given in the Errata.
} 
would then be printed along with the preface, title page and index before the book went on sale. ${ }^{30}$ Many of these stages are visible here. The text of the Fabrica ended on p. 824 on the last side of a gathering, Aa, that was unusually long, presumably so that all the text could be fitted in. This was then sent to Vesalius, along with the frontispiece and the prefatory material, for his consideration. The missing sheet, pp. 669-72, was included, for two corrections to these pages are noted in the Errata. Oporinus was still trying to borrow or buy from Strasbourg the moulds for the last two books in early May 1555, and it may well have been July before the proofs were ready to go to Brussels. Oporinus, according to the colophon, had finished setting the index by August, leaving the first page of the new gatherings, sig. Bb 1r., blank to receive the author's comments. Once they had been received - and Vesalius would have had no time to do more than prepare a list of some obvious corrections - publication could follow almost immediately.

An examination of the volume reveals no indication that the last gatherings with the index, sigg. Bb-Ee, were ever included. The grubbiness of the last page, p. 824, contrasts markedly with the near pristine p. 823, showing that it must have been exposed to the elements for some time, although much less than the frontispiece. The signs of the glue that held it to the vellum binding are also far more extensive than on the first and last pages of the other gatherings. That Vesalius did not have the proof sheets bound immediately is also clear from the fact that, as bound, some of the corrections on the inner sides of the leaves are now deep in the gutters. It is probable that the missing leaf was lost in the process of binding, but the cropping, as noted earlier, must have occurred at a much later date. Even after receiving a complete copy from Oporinus, Vesalius will have found it convenient to continue to use the proofs as his working copy. Not only would he avoid defacing the new book, but he would also have a draft easily available that, at some point in the future, he could send to the printer. That this was his intention is clear from the way in which he phrases his instructions (especially on the pages of the illustrations) and from his careful use of signs to indicate where marginal notes should go or when his words run over from one line to the next. Since he was planning a complete revision, there was no need for him to abide by the words of the 1555 Errata any more than elsewhere in the volume.

\section{Stylistic Changes}

Leaving aside the simple correction of typograpical errors, the changes introduced by Vesalius can be loosely divided into three categories: the purely stylistic, non-anatomical material and anatomical data. In the last two categories the deletions may be as significant as the additions, although it is not always easy to see why some passages have been left out, when others of a similar nature have been kept in. Even if the purely anatomical alterations are not as extensive or as significant as those made for the second edition, they nevertheless reveal that Vesalius retained an interest in dissection for several years after 1555 .

But to begin with anatomy is to misrepresent what Vesalius was doing and to impose our modern order of priorities. At least two thirds of the changes, including the correction

\footnotetext{
${ }^{30}$ Steinmann, op. cit. (note 11), 38f. and 47f. In general, see Anne M. Blair, Too Much to Know; Managing Scholarly Information before the Modern Age (Yale: Yale University Press, 2010), 52-5; Anthony T. Grafton, The Culture of Correction (London: The British Library, 2012). For the dates of printing, see O'Malley, op. cit. (note 2), 270. Steinmann's calculations from other books suggest that the last two books would have taken around a month to set and the index around 8-10 days.
} 
of earlier printers' errors, are concerned with words, and by far the great majority of them are stylistic. They do not alter the general meaning of the sentence, but display Vesalius' command of Latin and his constant concern about his choice of expression. Rather as a modern novelist might go over a sentence again and again to ensure euphony or tonal contrast, so Vesalius seems to have read and reread his Latin to improve the impact of his message.

The stylistic changes are so numerous that only a few examples can be given to illustrate their variety.

First, there are changes that Vesalius made purely to produce a more elegant Latin; they neither give another nuance of meaning nor alter the syntax of the sentence:

p. 4, 2 non tamen uniuersum os penetrant] uniuersum autem os non penetrant

p. 4, 10 quas manu obimur] quae manu obeuntur

p. 4, 13 from end effingunt, atque] effingant, ac

p. 25, 4 meminimus] memini

p. 92, 16 Transuersi autem] dein transuersi

p. 94, 21 ex usu fuit] defuit

p. 96, 6 from end is ] iste

p. 96, 2 from end non] haud

p. 101, 17 at] et

p. 206, 15 vero] autem

p. 275,13 tantummodo] dumtaxat

p. 359, 11 from end rursus] iterum

p. 362, 5 from end credamus] arbitremur

p. $376,30 \mathrm{cum}] \mathrm{ubi}$

p. 428, 23 Galeni descriptionem] Galeni historiam

p. 448, 4 from end at adaptare] adaptareque

p. 710, 1 existit] occurrit

p. 722, 34 insuper] etiam.

Sometimes, as on p. 68, 18-19, one change, quoque] etiam, demands another in consequence, etiam] quoque.

Often, as on p. 18, 9, proximis illi] proximis ipsi, the demonstrative is changed to avoid a string of identical words, or to give a little more precision, as on p. 27, 12 from end ipsi] huic. Elsewhere the word chosen is so rare that it may have defeated many of Vesalius' readers:

sig. A2r, 6 from end de Medici munere] de Medica officina

p. 86, 13 mucrones $<$ insinuans $>$

p. 120, 31 efformat] adipiscitur

p. 421, 21 superauit] perreptauit.

On p. 349, 6, opitularetur] suppetias ferret, one rare word is replaced by one that is even more choice and that on p. 423, 16 from end, is itself replaced by something simpler, accedit.

At other times, it is only the word order that is altered:

p. 209, 13 from end Graecis charactere] charactere Graecis

p. 417, 2 instituendus venit] venit instituendus

p. 427, 29 autoribus asscribantur] asscribantur autoribus.

There are also many syntactical changes, correcting the tense or mood of the Latin verb, as on:

p. 89, 2-3 deest... superest] desit... supersit 
p. 320, 14 habeant] haberent

p. 388, 16 from end offeret] offert,

or, sometimes, replacing a relative clause with a participle:

p. 51, 21 quoque... reponitur] repositum

p.357, 3-4 quod... insternitur] instratum

and vice versa:

p.615, 12 in duodenum insertus] qui duodeno inseritur.

Changes of this sort reflect Vesalius' consciousness of his position within the educated world, in which a scholar was judged on the quality of his Latin as well as on his learning. ${ }^{31} \mathrm{He}$ was particularly concerned to achieve an elegance of expression, which included the rhythm as well as the wording of his sentences, and to find a balance between the need for variation and the demands of precise description. William Richardson laments the sheer complexity of many of his sentences, which makes them difficult to render easily into English, but contemporaries would have appreciated his virtuosity as a Latinist alongside that as an anatomist. ${ }^{32}$ In this respect at least, Ludwig Edelstein was indeed correct when he emphasised that Vesalius was a true humanist. ${ }^{33}$

\section{Illustrations and Captions}

Vesalius paid as much attention to the visual as he did to the verbal. That was one of the great strengths of the Fabrica, and in Oporinus he found a printer who could help translate his ideal into reality. Throughout his teaching career, Vesalius used his own drawings, and those of others, to supplement or clarify his oral exposition. It is not surprising, then, that his changes to his illustrations are as significant as those to his wording. Some are in the nature of proof corrections, but others show Vesalius the artist as well as the anatomist.

On five occasions, he rewrote in the blank space of the illustration letters that had become almost invisible through excessive shading, indicating where they should go by a pointed arrow. ${ }^{34}$ In addition, on p. 241, fig., he replaced three letters, B, C and D, to make clear the triangle of musculature mentioned in his caption, while on p. 246, fig. and p. 247, 14 he changed the Greek compendium for o and $\mathrm{u}$ to the letter $\mathrm{N}$ as demanded by the sense and adjusted the caption to fit. He gave instructions as to how the mistake should be rectified. The cutter should inset a sliver of wood with the correct letter (imposito frusto ligni paretur $N$ pro ou). ${ }^{35}$

Vesalius' precision also extends to the drawings themselves, for he comments twice on mistakes made during the cutting of the blocks. On p. 232, fig., he explains the blank space left around a letter as a mistake by the cutter who in trying to make the letter thinner and clearer had removed the hatching for the tendon. Two pages later, 234, fig. bottom,

\footnotetext{
${ }^{31}$ For the background, see Françoise Wacquet, Latin or the Empire of a Sign from the Sixteenth to the Twentieth Centuries (London: Verso, 2001). Vesalius' Latin is only briefly mentioned in Wouter Bracke and Herwig Deumens (eds), Medical Latin from the Late Middle Ages to the Eighteenth Century (Brussels: Koninklijke Academie voor Geneeskunde van België, 2000), at 49-51.

32 Richardson and Carman, op. cit. (note 3), I, xxv-xxvii.

${ }^{33}$ Ludwig Edelstein, Ancient Medicine (Baltimore: Johns Hopkins Press, 1967), 441-54; Andrea Carlino, 'Les fondements humanistes de la médecine: rhétorique et anatomie à Padoue vers 1540', in Andrea Carlino and Alexandre Wenger (eds), Littérature et médecine: approches et perspectives (XVIe-XIXe siècles) (Geneva: Droz, 2007), 25-8. For his acceptance of Arabic authors, see Abdul Haq Compier, 'Rhazes in the Renaissance of Andreas Vesalius', Medical History, 56 (2012), 3-26.

${ }^{34}$ Pp. 43 A and A; 218 Q; 234, D; 244 u; 248 i. All these have been corrected in the forthcoming Karger edition through digital enhancement of the original images.

35 O'Malley, op. cit. (note 2), 129, notes a similar correction to the 1543 edition.
} 


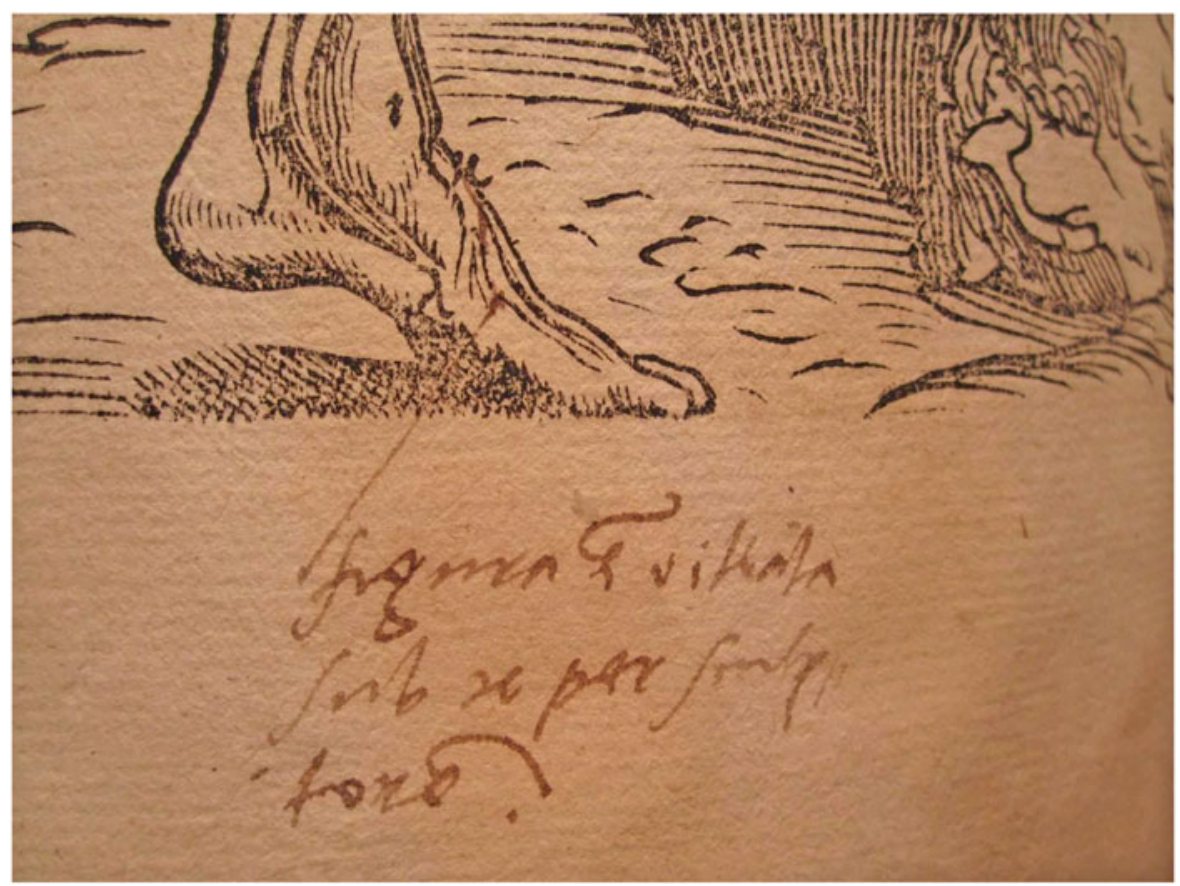

Figure 3: De humani corporis fabrica, p. 234. Vesalius redraws the outline of a toe removed when the blockcutter inserted the letter $\mu$.

figure 3, he notes that the cutter had caused a similar problem in trying to cut the Greek letter $\mu$ (figura est vitiosa sub $\mu$ per sculptorem), but this time Vesalius provides his own solution by redrawing with a very fine pen the outline of the toe himself for a block-cutter to follow. He seems to have followed a similar procedure on p. 259, fig., although here he does not explain what had happened, but places only a mark consisting of three parallel lines in the margin and a similar sign on the image. Vesalius also draws a thin line across part of the flayed muscle. What he intended is far from clear. There is nothing on this page or the next to suggest that this was to be an identification symbol, a Greek $\Xi$, linked to a text, and it is perhaps best to interpret this as an instruction to the cutter. Whatever was meant, it also shows Vesalius' precision and his own skill as a draughtsman.

There is one further change to a plate that differs from the rest. On p. 182, following the renewed discussion of what he claims to be cartilages in the eyelid, see below, p. 27, Vesalius redrew his image so that the cartilage in the upper lid takes the shape of a bell curve, figure 4 . This is the only change to an illustration that depends on a change of mind on the part of the author.

Alterations to the captions are more extensive. Some simply go back to the words or sentences that the typesetter had overlooked when he reset the pages in a more spacious manner, as on p. 109, 6, and some correct even earlier mistakes that had defied his and the printer's eye at least twice, such as the misplacement on p. 155 of the captions to KK and LL. On p. 245, 18-19 he deletes the clause et characteres...obuii, a revision of 1555 , and reverts to a simpler phrasing similar to that in 1543. Some of Vesalius' interventions, however, go beyond mere proof correction. On p. 207, ult., he notes in the margin that Celsus had used the word 'brachium' to mean the fore-arm 'contrary to all 


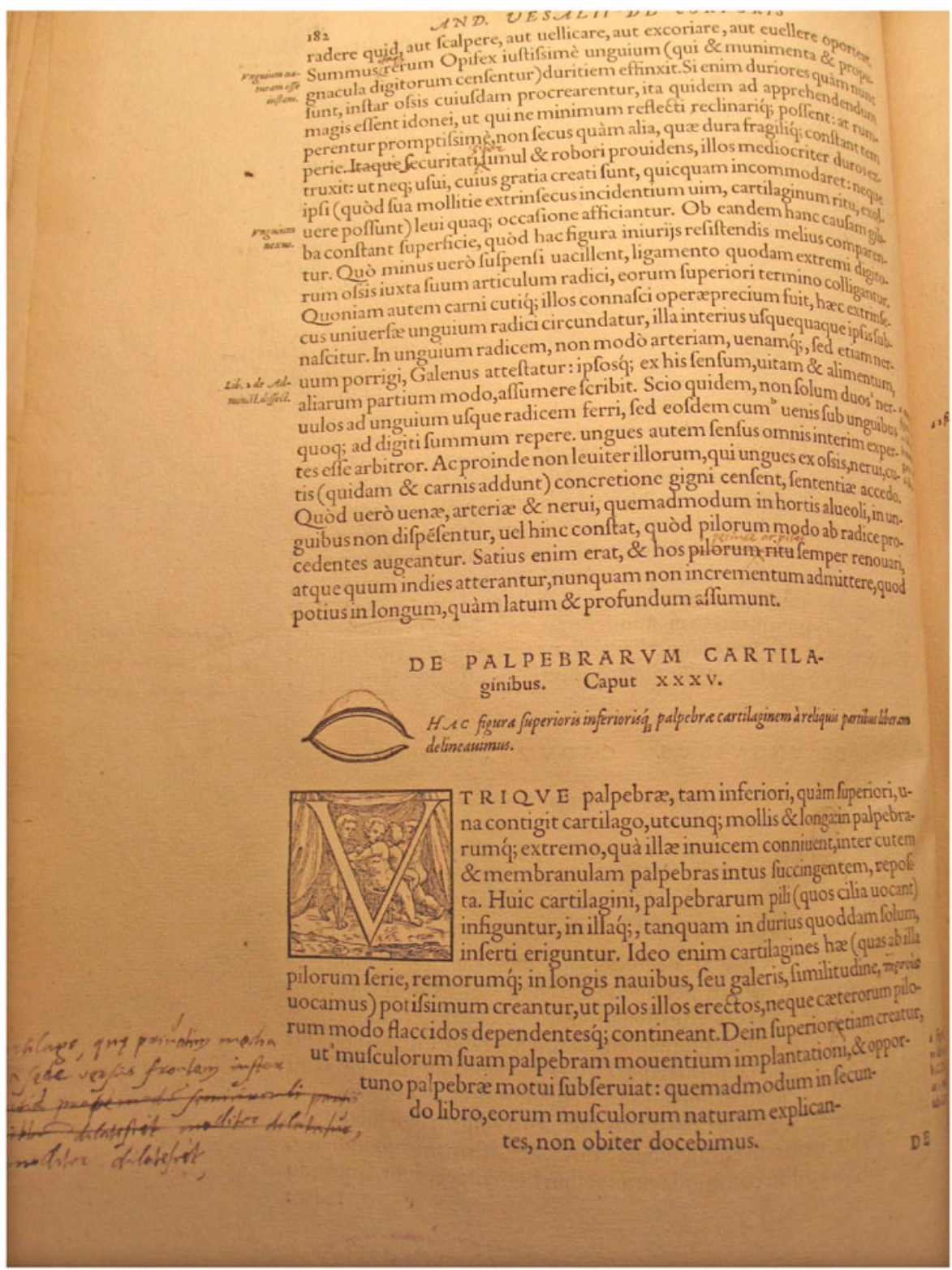

Figure 4: De humani corporis fabrica, p. 182. The redrawn eyelid.

medical custom' (a note that is presented differently in the 1555 Errata) and on the same page, line 15 from the end, adds the Greek word $\sigma \pi \alpha \dot{\alpha} \theta \alpha$ to the terms for ribs. ${ }^{36}$ But the great majority are made for the purposes of clarification or of conciseness.

${ }^{36}$ Celsus interim hanc corporis partem brachium [appellauit] praeter consuetam medicis omnibus rationem appellauit. A similar comment is made on p. 135, 2. See Celsus, De medicina, III, 1, 19-20; 10, $2-3$. 


\section{Sources and References}

Vesalius, as his opponents rightly argued, was adept at hiding his debts to others and, even when he chose to name those he criticised, they were rarely his contemporaries. He was correcting the mistakes of the past and only the acutest of readers could discern that the same improvements had already been made by some of his contemporaries. In his annotations, he follows a similar path. He adds references, some specific, to the great names of the classical period, Hippocrates, Celsus, Galen, Oribasius, Paul and even the orator Cicero. ${ }^{37}$ But it is impossible for the reader to know the source of the alternative term for the vertebrae, verticula, p. 72, 5 and p. 207, 23-4, or to divine who it was who had been so ridiculously concerned about the sexual activity of pregnant women that they imagined a channel leading from the ovaries directly to the cervix rather than to the cusps of the uterus. ${ }^{38}$ On p. 515, bottom, figure 5, his opponents are divided into two camps, both labelled as 'others' (alii), but his description of the opinions of the first group shifts from the pejorative 'they imagine' (confingunt) through the more positive 'they declare' (statuunt) to, finally, the neutral 'they reckon' (recensent). His own superiority is enhanced by emphasising that a wrong view is now 'widespread (vulgo)', p. 481, 13, and even the modest 'as far as I know' scarcely modifies his new assertion that his own discoveries about the glandules around the larynx have been neglected by 'other writers'. Indeed, the addition only intensifies the impression of Vesalius' scrupulous learning. ${ }^{39}$

The most striking of such additions comes late in the book, p. 653, bottom, figure 6, when, after discussing Pharaonic circumcision among the Egyptians, he refers to the custom of both male and female circumcision 'continuing today' for religious reasons in Ethiopia among the Scevani. These subjects of Prester John cut off the fleshy processes from new born girls in accordance with their religion in the same way as they remove the foreskins of boys, 'although in their religious ceremonies they are otherwise generally similar to those of us Christians'. ${ }^{40}$ This is arguably the first reference in a medical text to female genital mutilation for non-medical purposes, since Vesalius is unlikely to have gained his information from a medical source, as the context shows. That infant circumcision was practised by the Ethiopians had been known for many years, but it was not until the 1540s that Europeans became aware that it was also performed on young girls. ${ }^{41}$ The first to mention it in a religious context, as something that was instituted by the famous Queen of Sheba, was a Portuguese humanist who had never set foot in

${ }^{37}$ Hippocrates, p. 18, 9; p. 124, 6, p. 181, 28; Celsus, p. 129, 14; p. 135, 7; Galen, p. 516, bottom; Oribasius, p. 340, 11 from end (but then deleted); Paul, p. 640, 20; Cicero, p. 58, 14.

38 p. 668, 14 from end: vasa < simul cum seminis ductibus quo nonnulli de praegnantis venere ridicule solliciti ex testibus in uteri ceruicem praeter veros meatus in illius cornua confingunt $>$. Exactly what Vesalius meant by seminis ductibus is not entirely obvious. Carman, in his preface to the Richardson translation of the Fabrica, Book V, xii, decides that it means the uterine tubes. See Robert Herrlinger and Edith Feiner, 'Why did Vesalius not Discover the Fallopian Tubes?', Medical History, 8 (1964), 335-41.

39 p. 721, 24: et < prorsus quod sciam >, ab aliis scriptoribus neglectum.

${ }^{40}$ Quemadmodum hodie adhuc Sceuani Aetiopes \{dicto\} appellato nobis presbitero Janni < Abyssinorum regi $>$ subditi, nuper natis puellis carneos istos processus religionis ipsorum iure haud secus prescindunt ac masculis praeputia auferunt, et si interim Christianae \{alio\} religioni in caeremoniis \{alioquin\} alias pleraque habeant communia.

${ }^{41}$ Siegbert Uhlig and Gernot Bühring, Damian de Góis' Schrift über Glaube und Sitten der Äthioper, Äthiopische Forschungen 39 (Wiesbaden: Harrassowitz Verlag, 1994), 127, refers to Flavio Biondo, 'Historiarum quartae decadis liber II', in B. Nogara (ed.), Studi e Testi 48 (Vatican City, 1927), ch. 42, 25. 


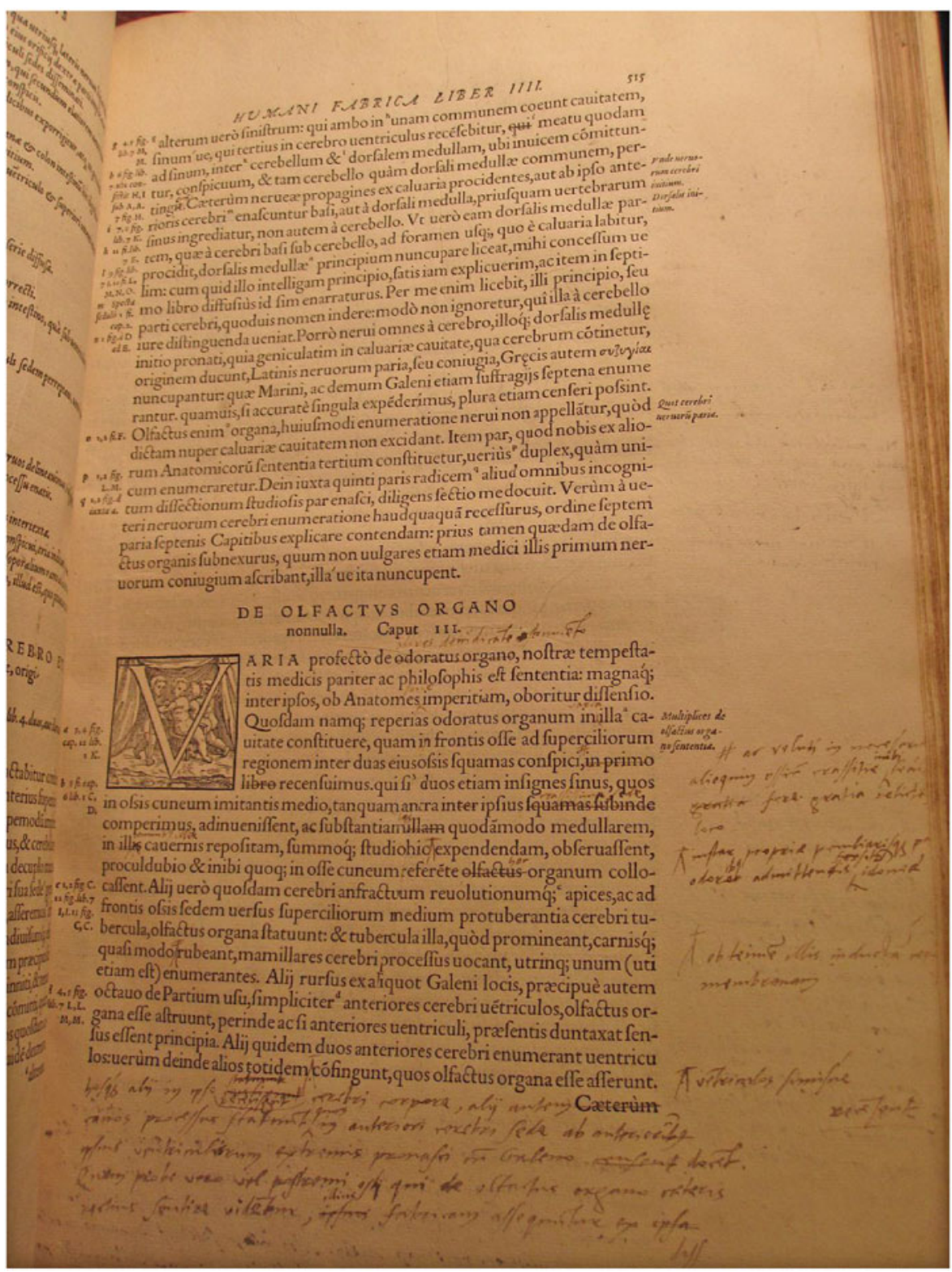

Figure 5: De humani corporis fabrica, p. 515. Vesalius on the organ of smell.

Ethiopia, Damian de Goes, in a controversial treatise on the faith, morals and religion of the Ethiopians, first published in $1540 .{ }^{42}$ But he cannot be Vesalius' source, since he does

42 Damian de Goes, Fides, Mores Religioque Aethiopum (Louvain: R. Rescius, 1540), 70 (available on-line in the edition, (Paris: Wechel, 1541), 69). For some of the religious background, see Andreu Martínez d'AlòsMoner, 'Paul and the other: the Portuguese debate on the circumcision of the Ethiopians', in Verena Böll, Steven Kaplan, Andreu Martínez d'Alòs-Moner and Evgenia Sokolinskaia (eds), Ethiopia and the Missions, Historical and Anthropological Insights (Münster: LIT Verlag, 2005), 31-51. 


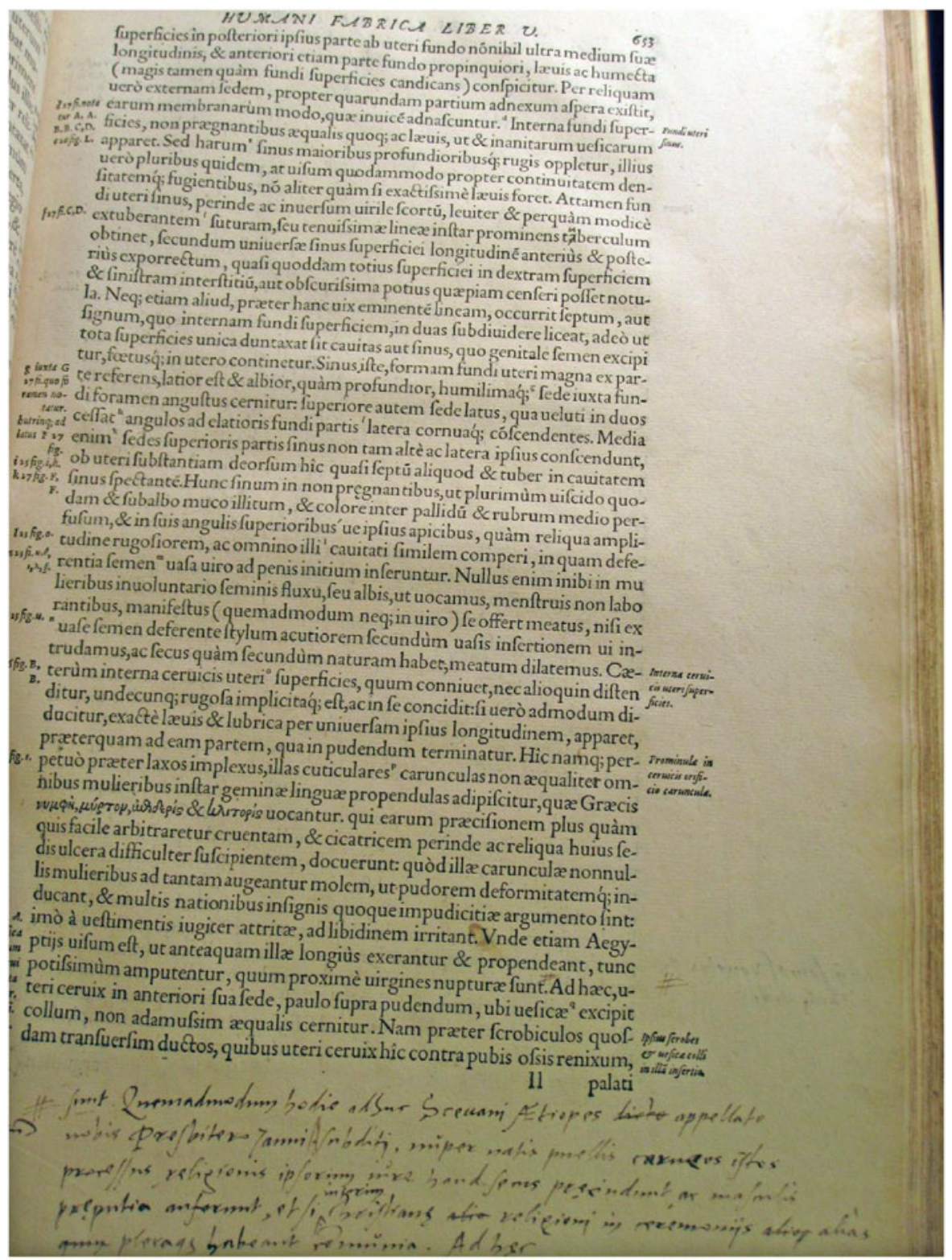

Figure 6: De humani corporis fabrica, p. 653. Female circumcision for religious reasons among the Ethiopians.

not specifically mention the Scevani. One author who does, whom Vesalius may well have read, is de Goes' collaborator, Paulo Giovio, who ascribes this custom to the Scevani in his history of his own times, published ten years later. ${ }^{43}$ Whoever was the source, Vesalius was sufficiently interested in his information to include it his discussion of the genitals.

${ }^{43}$ Paolo Giovio, Historiae sui Temporis (Florence: L. Torrentino, 1550), 304. 


\section{Deletions}

Deletions may also reveal almost as much about an author as his additions. Many of them here can be put down to a desire for concision, an unwillingness to repeat something that he has just said or will say later, whereas others, like the omission of his father's name, Andreas, on f. A5r, 22, or the much longer passage about the Ligurians and the information he received about the wording on their tombs, p. 111, 25-31, were perhaps made because he thought them now irrelevant. This may also be why he removes the comparison of human eyes to those of beetles and crabs, p. 283, 24, or of the length of a bone in humans and other animals, p. 132, 11, and why, p. 340, 11-8 from the end, he deletes a question and his own answer to it. He is a little kinder to Galen than earlier. On p. 18,9 he began by altering the syntax of his complaint before replacing the more aggressive 'I don't know what came into Galen's mind...' with 'I don't know why Galen...'. Nine lines which disappear at the end of the second paragraph on p. 65 (quare...prodidisse), contained a sneering attack on Galen for failing to recognise several of the foramina in the skull and for his many errors in relying on the anatomy of apes. ${ }^{44}$ In two instances, when describing how to dissect an eye, p. 287, 24-6, and a muscle of the arm, p. 390, 14-12 from the end, he removes an alternative method of procedure that he had allowed in previous editions. Allusions to other anatomists are excised on $\mathrm{A} 4 \mathrm{v}, 1$ and on p. 48, 12 , where 'teachers of dissection' are replaced by 'we', although Vesalius is by no means consistent in this. The long alteration on pp. 721-2, dealing with the glands in the throat, is a masterpiece of evasion. In the first edition, p. 579, he had remarked that the glands in the trachea at the base of the larynx had been called paristhmia by 'the Ancients', but he had refused to use the word in this sense until now because they had not been described by professors of anatomy. The implication is that this was a discovery of Vesalius. While the professors still remain in the revised passage, however, they are no longer his contemporaries but 'ancient professors', and any suggestion that they might have discussed this topic, let alone anticipated Vesalius, is removed. A related deletion concerns Vesalius' discovery of what he calls the muscles that open the lid of the larynx (rather, the epiglottic ligament). This claim remains in the description of the larynx on pp. 308-9 and in the much later discussion on p. 720 , but it is quietly abandoned at the first mention of this muscle on p. 274, 1, where the words 'discovered by us (a nobis inuenti)' are deleted.

Other deletions raise more questions than they solve. The removal of references to the purposes of the Creator on p. 5, 17-19 and p. 36, 3-7, may hint at the growing religious intolerance at the imperial court that made problematic any theological utterance unless ecclesiastically sanctioned, but other similar sentiments remain elsewhere, and on p. 5 the phrase 'the wise craftsman of the universe (sagax rerum opifex)' is retained in the margin. On p. 68, 19-9 from end, Vesalius' considerable reorganisation of original comments on the abbreviations used in the plate involves the disappearance of the injunction that he had given in the first edition, that one should use skulls rather than pictures because the sutures were clearer on the skull. This omission is hardly likely to have been an oversight, since the contents of the sentences that precede and follow it are preserved, although not verbatim. It is open to dispute whether this was because the comment was irrelevant in this context or because Vesalius acknowledged that by now the quality of images available to

\footnotetext{
${ }^{44} \mathrm{He}$ had first corrected his earlier (incorrect) reference to Galen's tract on nerves (signalled also in the Errata).
} 


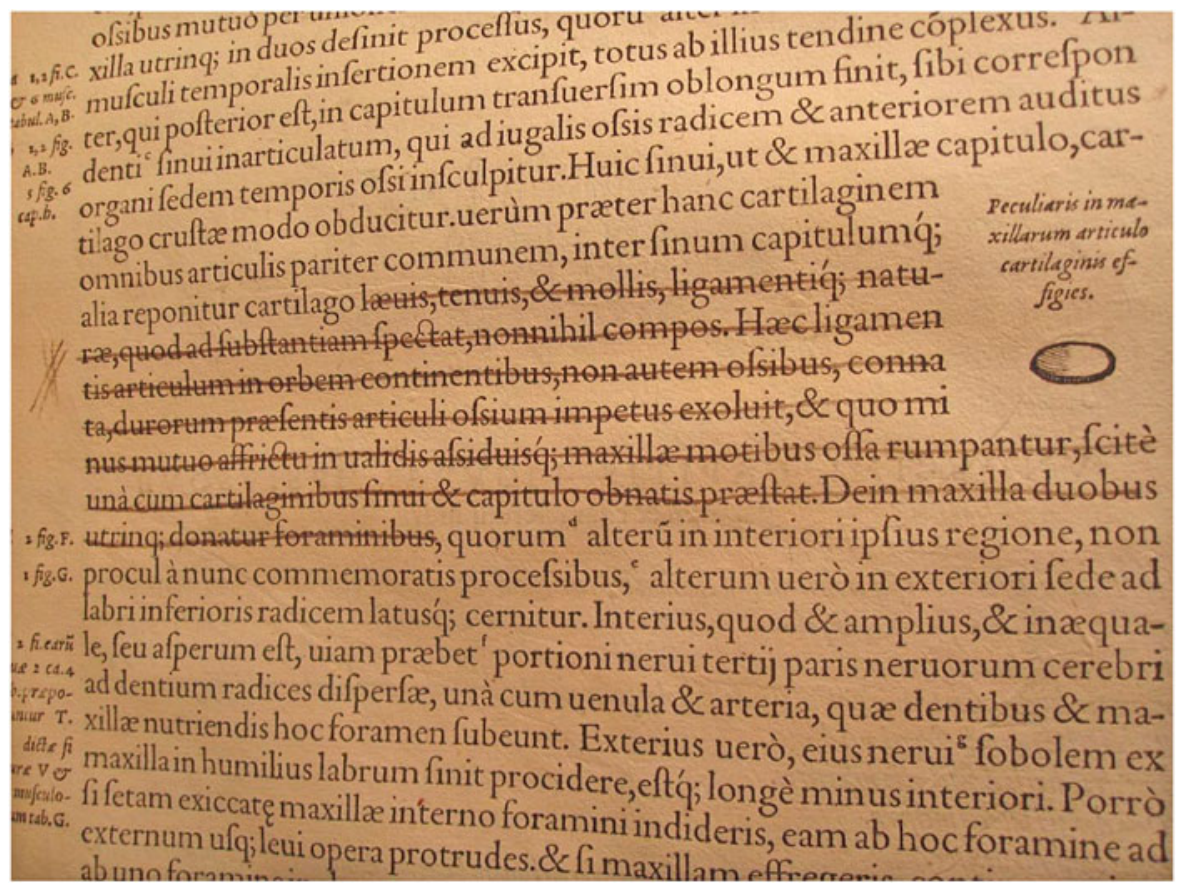

Figure 7: De humani corporis fabrica, p. 55. Vesalius deletes the section on the discus articularis.

readers had improved greatly, not least thanks to his own work and the copies that many derived from it.

But the most puzzling of the deletions comes on p. 55, figure 7 , and it is unusual in leaving an incoherent text. Vesalius at this point is drawing attention to the fact that, in addition to the cartilage common to all joints, there is a different cartilage, the discus articularis, which gives additional protection to the jaw bones. He describes it in detail and illustrates it with a drawing in the margin. The next section begins with a description of the two foramina in the lower mandible. Vesalius strikes out the whole section describing the disc and its purpose, as well as the opening words of the next section, from laeuis, tenuis, line 27, to foraminibus, line 33. This disc is not mentioned again. This is the longest specifically anatomical deletion, and it is carried out so clumsily that the careless reader might well believe that the alternatives discussed in the relation to the mandible are the two foramina of the next section. Even if Vesalius had come to the conclusion that there was nothing special about this disc, or even that he had found an anomaly, he deleted only the text, allowing the illustration to remain unchanged. The removal of the opening part of the next section could be a mistake by Vesalius, although his manner of deletion, which shows the pen quickly moving on the page from left to right on each sentence, suggests that this was no accident, but was done to allow the sentence to flow easily from the two types of cartilage to the two foramina. But why he should have decided on this change is far from clear. Had Vesalius found evidence that showed that similar discs could be found elsewhere? Or did he regard this simply as an anomaly that need not be recorded in detail again? 


\section{Qualifications}

Far more than in the second edition, Vesalius modifies some of his general statements with adverbs or phrases. One might dismiss as a literary affectation his description, sig. A4r, 14 , of the corpses available to Galen as 'perhaps' (forte) dry and almost skeletal, but the addition subtly moves the comment away from an excuse for Galen's failure to examine the interior of a human body. On p.43, 1, his comment that nothing but bone separates the temporal muscles from the brain and its membranes is qualified by the addition of 'almost' (ferme). The upward movement of the spine, p. 91, 3, is made 'in some way' (quodam modo). In an addition to what is already an addition in the second edition, $\mathrm{p}$. 127,5 , the area surrounding the articulation of the cartilage at the joint of the clavicle, which had been described in the previous chapter, is first described as 'with flat surfaces' (planis), and then this in turn is qualified by 'almost'. ${ }^{45}$ Some of these qualifications may reflect an awareness of possible variations and anomalies, others his sense of the difficulty of capturing in words the precise appearance or feel of the body.

\section{Anatomy}

In his annotations Vesalius makes no overt claim for any new discovery, nor is there any clear reference to the dissection of a corpse. This is hardly surprising since his position at court took him away from academic life and, as he complained in the Examen, once he moved to Madrid, it was difficult even to obtain a skull. But that complaint also implies that he was able to do some anatomical work even there. How far that is reflected in the annotations is difficult to say, not least because of the absence of any criterion for dating. Comments made shortly after 1555 would naturally be expected to contain fewer novelties than if they had been made in 1563. Nonetheless, Vesalius is (re)writing an anatomical treatise and even some of his linguistic changes may throw light on his anatomical knowledge and reasoning.

It is easy to forget when reading a text like the Fabrica that it is an anatomical exposition based on hundreds of dissections and incorporating advice to guide the student to dissect for himself. Consequently, many of the changes now introduced are meant to make things easier for the practitioner. Some of them are small, reflecting the author's awareness of the difference between a description or an image on a page and the three-dimensionality of a body, as well as the position of the corpse lying on the slab as it is being dissected. So, p. 298, 10 exteriora ('outer') is replaced by antrorsum or anteriora ('frontwards/front'), and on p. 516, 12, deorsum ('downwards') by retrorsum ('backwards'). Far more often, the adjective is made more specific. Grandis ('big'), and its comparative and superlative forms, can be replaced by forms of magnus ('large') with no change of nuance, but crassus ('thick'), amplus ('broad'), durus ('hard') and even insignis ('prominent') distinguish one part of the body from another by an appeal to other types of perception. Likewise, the interchange of 'small' (paruus), 'slender' (tenuis) or 'thin' (exilis) adds something extra to the bare description. ${ }^{46}$ The substance in the cavities of the brain becomes 'almost more

\footnotetext{
45 hic $<$ ne scilicet $<<$ planis $<<<$ propemodum $>>>$ superficiebus constans $>>$ contextus satis dirueretur $>$. The number of successive additions, three in all, is unusual in these notes.

${ }^{46}$ E.g magnus, p. 129, 3 from end; p. 145, 28 and 35; p. 177, 3-2 from end; p. 485, 6 from end; p. 493, 6 and 10; crassus, p. 469, 28; p. 478, 33; p. 484, top; p. 486, 26; p. 516, 8 from end; p. 525, 9; amplus, p. 489, 2; p. 492, 25; p. 503, 6 from end; durus, p. 17, 10 from end; insignis, p. 492, 1; p. 496, 7; tenuis, p. 486, 28; exilis, p. 503, 6 from end.
} 
membranous' as well as more callous on its external surface. ${ }^{47}$ The cartilage between the carpus and the ulna is described, p. 139, 11, as 'smooth and slippery on both top and bottom' (supra infraque leuem et lubricam). At the very least these are reminiscences of dissection, of how a body part felt or appeared in relation to others, even if it cannot be proved that this was the result of recent dissection. Nonetheless, the concentration of these small changes in discussions of bones and the skull, since these were, on the whole, relatively easy to obtain, may count in favour of Vesalius' continued activity as an anatomist after 1555 .

There is no evidence in the annotations, however, that Vesalius was able to cut up a corpse, and his comments and criticisms relate overwhelmingly to the first two books, on bones, muscles and ligaments. But his most surprising novelty comes with the very last annotation of all. At the bottom of p. 805, figure 8, he adds two sentences to his discussion of the aqueous humour:

Because when we are dissecting the eye, the amount of this humour that emerges is small and scarcely comparable with the large amount of vitreous humour, one must conclude that it is largely composed of a sort of spirit and aerial substance that occupies the place between the lens and the pellucid corneal tunic that we generally give to the aqueous humour. Although perhaps someone [might say] that the vitreous humour occupies a larger space in the eye than the rear portion and thus that the lens along with the vitreous humour [is placed] off-centre in the front part of the eye. ${ }^{48}$

Vesalius himself in his plate on p. 798 and in the introduction to this chapter had been firm in his conviction, shared with earlier anatomists, that the lens divided the eye into two equal cavities. It was Vesalius' successor at Padua, Realdo Colombo, who is usually credited with the discovery that the lens is at the front of the eye, although his formulation and the drawing of the eye published soon after by the Basle professor Felix Platter indicate that they believed that the lens was not placed at the very front of the eye but only a little forward of centre. ${ }^{49}$ Vesalius' second suggestion, which appears to be derived through logic, would place the lens much further forward, with only a tiny space to be filled with aqueous humour. Nonetheless, whether this correction derives from Vesalius' reading of Colombo, and is deliberately disguised, or simply from thinking about a (new?) observation, he did not attempt to confirm it by a new dissection, and there is no indication in the immediately preceding passages that he returned to correct them after having had this thought.

With one exception, this pattern of scattered observations and factual additions amid a multitude of stylistic, didactic and simple proof-correction changes is typical of the last five books. Some of Vesalius' comments may derive from what he had seen during a dissection. The spleen, for instance, 'sometimes shows the impression of the ribs under which it lies', while the foetal sac is attached more strongly to the rear of the uterus,

\footnotetext{
47 p. 788, 17: callosior < et veluti membranosior $>$.

$48<$ Quia vero huius humoris dum oculum dissecamus parua \& vitrii humoris mole vix comparanda occurrit portio, colligendum est illam magna ex parte spiritu quodam aereaque substantia constare eam sedem occupante, quam aqueo humori inter crystallinum et corneam tunicam pellucentem alioquin vulgo tribuimus. Quamuis enim forte quispiam humorem vitreum ampliorem oculi sedem \{implere\} quam posteriorem implere hincque crystallinum simul cum vitreo extra centri regionem in anteriori ... $>$. There are traces of two or three letters on the line below, which has been lost in the process of binding, but the overall sense is clear. The question of whether there was 'spirit' in the eye was hotly debated.

${ }^{49}$ Realdo Colombo, De re anatomica (Venice: N. Bevilacqua, 1559), 219: situs quoque eius est anteriora versus, pene in centro oculi. For Platter, Huldrych M. Koelbing, Renaissance der Augenheilkunde, 1540-1630 (Bern and Stuttgart: Verlag Hans Huber, 1967), 68 and 74. One referee points out that, once the bulbus had collapsed after any leakage of the aqueous humour, it would not have been easy to determine the location of the lens.
} 


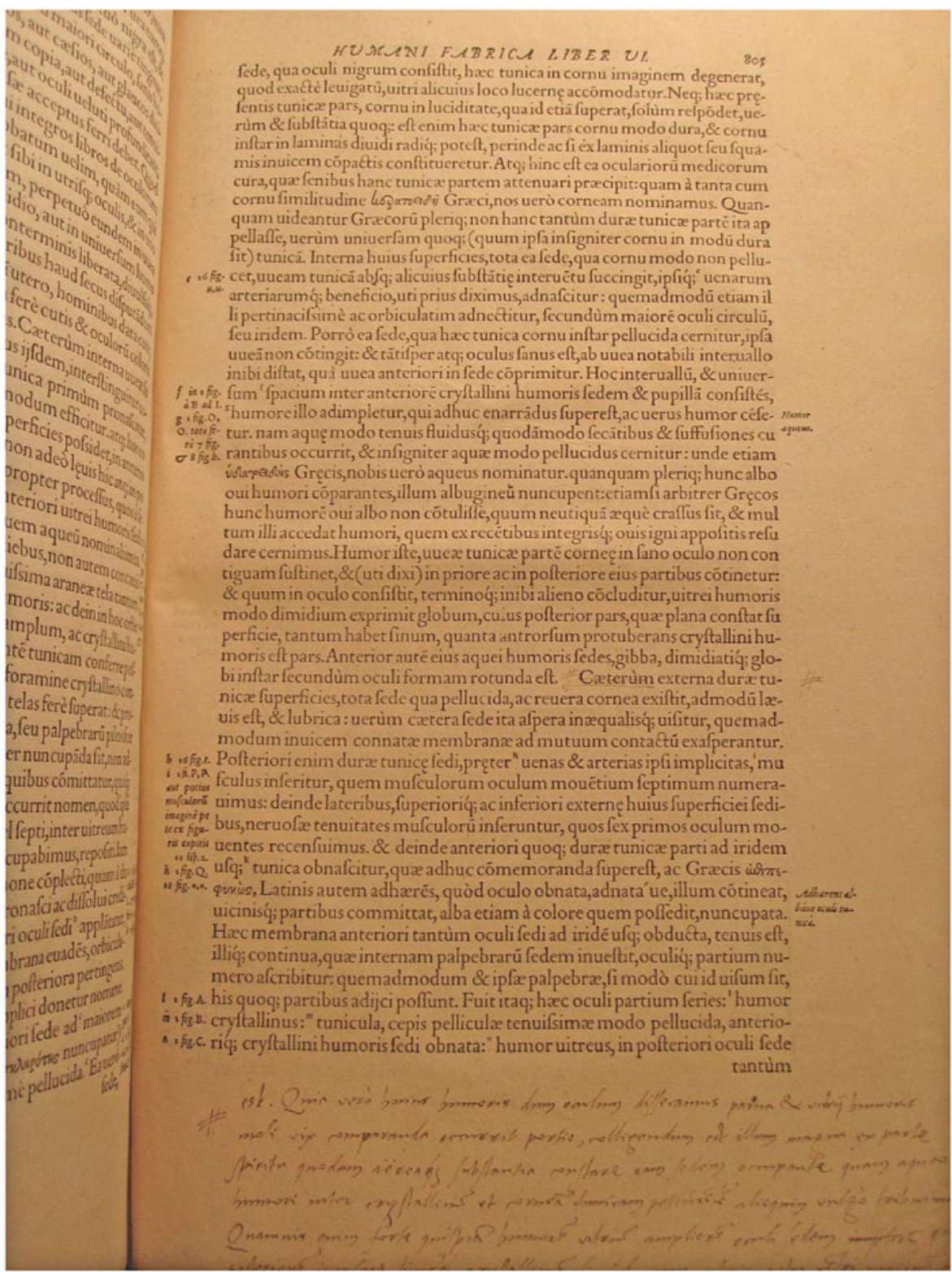

Figure 8: De humani corporis fabrica, p. 805. By meditating about the aqueous humour, Vesalius suggests that the lens is placed much closer to the front of the eye.

because the vascular network is particularly dense there, and a private receptacle for the urine of the foetus is located between two of the wrappings of the womb. ${ }^{50}$ Others may be

${ }^{50}$ p. 626, 22: (lien) < nonnumquam costarum quibus incumbit impressiones referens >; p. 481, 27: parti< quae potissimum in muliere posterior existit $>$.. illi $<$ priuatoque foetus urinae receptaculo inter duo vera illius inuolucra subinde coniuncta $>$. The comments on the foetus are interesting in that this section had been heavily revised in the second edition. 
thoughts occasioned by reading. The sexual organs of generation were formed by Nature in such a way that 'through sexual intercourse they might create one living being'. ${ }^{1}$

The one exception comes on pp. 515-19, where Vesalius discusses what in the previous editions he called 'the organ of smell', De odoratus organo. The subject is now changed to 'The instrument that distinguishes smells', De odores deiudicante instrumento, a change that both minimises Vesalius' dependence on Galen's treatise on the same theme, De instrumento odoratus, and implies a different and more complex approach to this and other organs of perception. ${ }^{52}$ Despite the abundance of annotation, however, these pages deliver less than they promise, for two reasons. The first is that Vesalius himself was not entirely sure what he wished to say at this point. No other alterations are reworked so often. Sentences are written and rewritten, only to be deleted, and even some of the changes introduced to clarify what he had originally said are themselves revised. ${ }^{53} \mathrm{He}$ is clearly interested in how the pathways of sensation are created in even the thickest of bones and in what makes a part particularly suitable for admitting odours. ${ }^{54}$ But he makes only one major new observation. Instead of saying that there is a soft, white substance emerging from the brain, he declares that it is a soft white process that is drawn out like a nerve. ${ }^{55}$ The second reason is that he planned to say more about the channels and the foramina leading from the nose to the dura mater and the brain when he came to revise book VII, and instead concentrated at this point on simply listing the nerves. ${ }^{56}$ But he never alludes to these plans in his revision of Book VII, either because he had by then forgotten what he had said earlier or because the notes here were in fact written after he had gone through the whole volume at least once and he died before he had time to revise Book VII again.

The annotations to the first two books are more extensive, although they largely only clarify or expand on what had already been said. On p. 169, 7, however, he first follows the Errata in adding a negative to the new sentence about the junction between the tibia and fibula, and then decides to delete the whole sentence. Sometimes he reports apparently new information. As part of his proof of a channel leading from the mouth to the ears, he adds to his earlier comment about what happens if one tries to blow out air through one's ears his experience that if some liquid is poured into the ears, its qualities and

${ }^{51}$ p. 638, 12 from end: extruxit, ut < quum simul commiscerentur coirentque ac (so?)luti unum animal crearent $>$.

52 On p. 517, 5 he draws a comparison with the visual nerves in a dog and other animals: unaque forsitan expenderunt oris canis aliquotque (for aliquoque?) brutorum processu neruorum visoriorum crassitiem \{triplo\} vel triplo vinculo (?) turgidaeque admodum et eductae papillae speciem. $>$.

53 On p. 516 the sentence running from conscendere... dicebamus began with angustos iam dictos terminos conscendere incipiunt in cerebri basis medium cessantes. in...cessantes was then deleted and replaced by ad cerebri basim; ad was then in turn deleted and basim replaced by basis before the whole sentence was altered completely and replaced by Non procul ab hac cerebri parte qua angusti ventriculorum termini inter cerebri anfractus (desin)unt (...) que iuxta cerebri basis medium. Transcription is complicated by the crossings out and by the trimming of the margin.

54 p. 515, 6: conspici < ac veluti in necessariorum alioqin ossium crassitie $<<$ inibi $>>$ sensus $\{$ gratis $\}$ fere gratia relicto loco >; line 9: < instar propriae peculiarisque partis odoribus admittendis $<<$ forsitan $>>$ idoneae $>$.

55 p. 516, 26: albus mollisque < et nerui in modum longus educitur processus $>$ \{prodit substantia\}.

56 p. 517,top: < Quemadmodum vero haec, ita quoque haud negligendum est, quonam pacto isti de quibus agimus processus suis finibus durae membranae \{adnascuntur et cum nulli quapiam penetratione adnascuntur, et quae foramina huius membranae et ossium similes processus admittentibus ad super commemoratas frontis ossis et cuneo correspondentis ossis cauernas pertingunt quo \{scriberetur promptius\} odores discernentis organi naturam septimo libro \{pertractemus\} promptius absolutiusque pertractemus. In neruorum namque historia \{suffici\} sat est dictam seriem explicasse, quos $>$; then follows line 2. Vesalius' uncertainties in wording can be seen clearly. 
sometimes even the liquid itself can be felt to drip into the cavity of the mouth. ${ }^{57}$ His investigations into the eyelids have shown that a cartilage in the middle of the front of the eyelid helps to dilate it gently, a procedure that he illustrates with a drawing. ${ }^{58} \mathrm{He}$ says rather more about this 'peculiar' cartilage in a much changed addition in the margin of p. 4 that emphasises the way in which it supports the upper eyelid. ${ }^{59}$ The cartilage at the wrist is rather like a ligament, but soft, not only allowing an easy articulation when being moved up or down, but also preventing a gap appearing between the arm and the wrist. ${ }^{60}$ The cartilage at the knee also permits the lower leg to be flexed easily. ${ }^{61}$ In two passages hard to decipher because of his changes of mind, Vesalius rephrases his ideas about teeth, where the gums offer some protection, and where there is some variation in the number of canines and incisors, but not of the five molars on each side. ${ }^{62}$ The humerus in the ape is different from that of man, an indication of Vesalius' interest in comparative anatomy. ${ }^{63}$ Sometimes he adds a short explanation to what he had written. He has not given identifying letters to the small bones in the foot 'because they are not universally present as such'. ${ }^{64}$ Sometimes he expands a little. The sixth of the thoracic muscles 'may communicate with the intercostal muscles'. ${ }^{65}$ The muscles between the lowest rib and the ilium not only cover a space without bones but one that is 'soft'. ${ }^{66}$ Other corrections simply repeat with slightly different and usually clearer wording what had been published in 1555 .

What light do these annotations throw on Vesalius' activities as a dissector after 1555? This is not an easy question to answer, especially in the absence of any date for the annotations, but one thing is clear. Vesalius continued to consider himself a dissector and to be interested in the results of dissection. Even if, on p. 805, 18 from the end, his use of the plural and the present tense, 'we dissect', dissecamus, is ambiguous, for it can refer solely to Vesalius or, more likely, encompass his future readers also, it shows that he still regarded himself first and foremost as a dissector. He is full of advice that can have come only from someone experienced in dissection. So for example, in order to prevent a small

${ }^{57}$ p. 65, 14: Imo foraminis huius occasione, liquorum qui ante infunduntur qualitas et interdum ipsa etiam substantia in oris am(pli)/tudinem (?) manare sentiuntur. The cropping of two or three letters in the right margin makes transcription difficult, but the sense of the passage is not affected. Iain Donaldson comments that this would happen only if the eardrum had been perforated and wonders if that was true of Vesalius himself.

58 p. 182, 5 from end: Dein superior < cartilago, quae priuatim media in sede versus frontem $\{$ instar $\}$ propemodum fronticuli gibbum dilatescit molliter dilatatur (all from frontem to dilatatur is then crossed out and replaced by molliter dilatescit). What Vesalius describes as a cartilage may well be the levator muscle, see below, p.

${ }^{59}$ p. 4, 6 from end: h]ic quoque palpebrarum extra/...s quibus illae conniuent $\{a d / . .$.$\} istae cartilagines$ harum laxi/(ta)ti ossium instar succurrent et has superiori palpebrae peculiaris est cartilago. Ille mag(is) etiam musculorum insertionem (c)ontinue admittit $\{$ Et palpebrarum laxitati continue succurrentes $\}$. Praeterea.... For the significance of this claim by Vesalius, see below, p. 27.

60 p. 139, 14: < praeterque quod haec cartilago (lig?)/amenti natura participans ita/ utrimque mollis eleganter (quum (?) licet prompte comprimitur tolliturque rursus) laxam ha(bet?) ossis articulationem, plus in iis illorum motibus dehiscere prohibet $>$.

${ }^{61}$ p. 168, 9 from end:< et simul laxo utrumque in tibiae flexu motui continuo hac cartilaginis temperie succurvatur $>$.

62 pp. 4, 14-18 and 58, 9. The loss of words in the margin precludes an accurate transcription, but the overall message corresponds to that in the text.

63 p. 132, 11: < nam in simii humero hic hac in parte $\}$ aliquid est distinctius $>$. For other references to animals, cf. Vesalius' annotations on pp. 124, 130, 363, 470.

64 p. 175, 32: ossicula $<$ quod etiam universa non sunt ipsa $>$.

65 p. 235, 14: musculus $<$ quem interius intercostalibus musculis $<<$ etiam $>>$ communicare \{nihil prohibet $\}$ licet $>$.

${ }^{66}$ p. 334, 9 from end: quum inter ilium os et infimam costam velut mollia et ossibus inania destitutaque sunt. 
bronze instrument from breaking off when it is being twisted, he recommends that the metal should be heated until white hot and then 'plunged almost entirely into water to be cooled' ${ }^{67}$ On p. 287 he offers advice about how to cut into the skull, should one wish to see the muscles of the eye still in place in the skull, and how to remove the heads of the muscles in such circumstances. ${ }^{68}$ Many small changes of wording also reflect his experience with the knife, as well as a desire to make his instructions clear to those planning to cut up bodies after reading his book. Vesalius dictates the questions to be asked, as well as the methods for their solution. So, for example, 'When you have freed the thoracic muscles from the bones and cartilages of the thorax, you should investigate which movements they initiate and which muscles also serve as protection for the intercostals' ${ }^{69}$ At the very least, the annotations reflect his own experience as an anatomist, familiar with the shape, size, texture and arrangement of the body.

How much of this derives from recent dissection is far from clear. There are no major changes to what he had published in 1555 , and the one discovery, if that is its correct name, the location of the lens in the eye, above, p. 21, is derived from meditating on the results of a dissection perhaps recollected from the past. Significantly, what is obviously a logical conclusion is not followed up by a dissection of the eye itself. But if one looks carefully at where the annotations and revisions cluster, they confirm that Vesalius had not carried out any new large-scale dissection, and may not have had the opportunity to do so. $\mathrm{He}$ comments at length about teeth, pp. 3, 58, the bones of the hand and foot, pp. 153-4, 175, the sesamoid bones, pp. 172, 190, the ribs, pp. 334, 352, the legs, pp. 407-8, the tonsils, p. 721, and the eye and the eyebrow, but says nothing about the major internal organs. The longest continuous series of alterations comes on pp. 515-8, figure 5 above, where he discusses at length the connections between the nose and the brain, and clarifies some of their anatomical details. It would not have been impossible to obtain some of these bones, even in Spain, and his references to animal anatomy indicate another source of specimens. But, in short, there is no new anatomical material on the scale of the changes introduced in the 1555 edition and, what is even more striking, little or no engagement with contemporary anatomists, a feature that may throw light on the dating of the notes and their subsequent history.

\section{Missing Persons and a Possible Date}

The simple process of reading through more than 800 folio pages even once is timeconsuming, let alone when combined with the care needed to pick out a missing ' $\mathrm{i}$ ' or replace a comma with a full stop or a semi-colon. At the very least, one must imagine that after 1555 Vesalius spent a good deal of his free time with his book, seeking to improve it and pondering on some of the results of his and, perhaps others', dissections. ${ }^{70}$ Such a thorough and careful, if not obsessive, reading will have taken months, if not years, to

\footnotetext{
${ }^{67}$ p. 196, 3 from end: candescat < dein citra submersionem in aquam refrigeretur $>$.

68 p. 287, 6 from end. The sentence Caeterum ... deducens is expanded to Caeterum si oculi musculos in ipsa caluaria administrare animus es, posteaque superiorem sinus ipsius quartam trianguli in modum serra ademisti, neruo visorio a calvaria non resecto $\{$ ad eum quem primum dixi modum $\}$ musculorum capita ab illo sensim auferes, ipsosque ad insertionem deduces.

${ }^{69}$ p. 352, 2-5: hos ubi a pectoris osse et cartilaginibus liberaueris cuiusque motus autores sint quique intercostalibus quodammodo admuniculi sint indagaueris, intercostalium musculorum sectionem absolues, corde, pulmone, venis, arteriis, stomacho et siquae alia in thoracis capacitate habentur ablatis.

${ }^{70}$ Dan Garrison reminds me the Epistle on the China Root, which will be published in his new English translation by Cambridge University Press in 2012, shows a similarly heavy involvement with the first edition of the Fabrica
} 
complete, without taking into account that, to judge from the slight differences in script, Vesalius sometimes went back to add or delete a passage. It was only death, one might assume, that put an end to his preparations for the new edition.

Recently, Jacqueline Vons, without knowing of these annotations, has offered a suggestion that might indicate a date of composition before $1564 .{ }^{71}$ She suggests that Vesalius took advantage of the bad weather that delayed his departure from Venice in spring 1564 to hand over to his new printer, Francesco de' Franceschi, a manuscript of the Fabrica. This was eventually published in 1568 in a smaller format and with the woodcuts redrawn. ${ }^{72}$ Although the existence of this edition is well known to bibliographers, it has been largely neglected by historians. ${ }^{73}$ O'Malley is silent about it in his biography of Vesalius and the bibliographers have said nothing about its contents that would attract the attention of those wishing to follow the development of Vesalius' ideas.

But, tempting though it is, this suggestion can be firmly ruled out. De' Franceschi, who in his foreword to the Examen had explained his relationship to Vesalius at length, here says nothing, except to praise Vesalius for applying 'himself to anatomy even in the midst of his important duties and nightly cares ... and making a second illustrated edition' (in summis alias laboribus ac vigiliis... et secundo illustratum edidit). All that he himself had done was, with great expense and effort, to reduce this monster to a small size, for the benefit of students, especially the poorer among them, and to have the plates recut by the Pomeranian, Johann Crieger. ${ }^{74}$ He was telling the truth. He included none of the factual changes here indicated by Vesalius, his block-cutter still left out some of the lettering that was obscured in the 1555 edition and, in effect, he reproduced the 1555 edition largely unchanged. He corrected some, but not all, of the mistakes listed in the 1555 Errata, but left some obvious errors unaltered and introduced some of his own. ${ }^{75}$ This volume and its annotations thus cannot be the author's copy handed over to a Venetian printer. Given that Oporinus still retained the original blocks for the plates, there can be little doubt that Vesalius still regarded him as the best person to produce his next edition, since his comments on the plates presume access to the original blocks.

However, Vesalius' silence about his contemporaries does suggest another date for the completion of these notes as we have them. Personal animosities may have prevented Vesalius from alluding to Colombo or Valverde, but the absence of any reference to two other anatomists, Falloppia and Ingrassia, is puzzling. Falloppia had published his Observationes in 1561 and Vesalius' reply is dated from Madrid in December $1561 .^{76}$ His response was cordial, setting out some of their differences and commenting on his own earlier experiences when investigating similar material. Much of what Falloppia had to

in the years immediately following its publication. Vesalius' notes on the Institutiones, above, n. 24, show a similar pattern.

${ }^{71}$ Vons, André Vésale, XXXIII, but mistaking the ethnic of the printer ('from Siena') for his surname.

72 Andreas Vesalius, De humani corporis fabrica (Venice: F. de' Franceschi, 1568).

73 Harvey W. Cushing, A Bio-bibliography of Andreas Vesalius, 2nd edn (Hamden: Conn.: Archon Books, 1962), 91-3 no.VI.A.-4, giving the most detailed account available of this edition; Cockx-Indestege, op. cit. (note 9), no. 34 .

74 Vesalius, op. cit. (note 72), sig. *6v.

${ }^{75}$ For example, he does not include the corrections listed in the Errata on p. 9, 32; p. 17, caption, 1. 12; p. 632, caption, 1. 3; on sig. A 2v. 20 he inserts familiae instead of familia, and on p. 573, 3 relicto instead of relicta. The obvious transposition on p. 155, 15-20 is not made, and the captions on p. 243 are headed DUOCECIMAE. Many of the changes not taken over from the Errata relate to punctuation of the captions, but they are missed nonetheless.

76 O’Malley, op. cit. (note 2), 289-96, describes succinctly Vesalius' reactions to Falloppia's discoveries. 
say Vesalius accepted, at least up to a point, and even if the epistolary mode constrained Vesalius in what he could say, he nevertheless seems to have been willing to change his views on many topics. What Falloppia had said about the teeth pleased him very much; his discovery of a muscle raising the eyelid is given careful consideration among various possibilities; and his criticism of Vesalius' belief in venous fibres controlling the flow of blood is graciously accepted. Other points were more controversial, such as the name of the psoas muscle or the exact description of the ginglymus hinge, and it is not surprising that they do not figure in the notes. But it is striking that none of Falloppia's novelties are in any way recorded there, even when they appear to have found favour. Discoveries made by others and accepted by Falloppia are likewise omitted. Vesalius admits that he knew by then of Colombo's discovery of the levator palpebrae superioris, at least by hearsay, while at the same time confessing that he interpreted differently what he himself found when performing that dissection. ${ }^{77}$ This is the 'cartilage' that is referred to several times and drawn by Vesalius in his notes, above pp. 13-4. In another passage in the Examen, Vesalius remarks that he had heard of the discovery of the third ossicle of the ear, the stirps, the stirrup, from a report, probably by Valverde, of what Ingrassia had found, and that he had confirmed it for himself by dissection. ${ }^{78}$ Although Vesalius comments in his notes on the structure of the ear, and particularly the auditory meatus, he says nothing about the stirrup bone at all.

Vesalius' silence in his notes can be interpreted in two different ways. He may not have known of these new discoveries at the time he was writing or he may have wished to disguise his own failings. The former is the more likely, especially as he was prepared to acknowledge others' priority in the Examen. It would also accord with a major change in his circumstances, his move with his wife to Madrid in 1559. If, as is likely, he retained his house in Brussels, he may well have decided to keep some of his library there and not to transport this large and cumbersome volume to Spain. ${ }^{79} \mathrm{He}$ would have had time to read through this volume and make many small changes, but not to make any major new discoveries or to have heard of what Colombo, Falloppia and Ingrassia had found.

But there is another intriguing possibility, pointed out to me by Martin Steinmann. When Oporinus sold his business in 1567, the Fabrica, along with the blocks, was one of only two books that remained with Oporinus, although the new owners were allowed to sell it on commission. ${ }^{80}$ Two years later, after Oporinus' death, one of Vesalius' heirs, Franciscus Maria Stella, wrote to Basle to reclaim the wood blocks for the Fabrica, all the printed copies still left, as well as the printers' copies and a considerable sum of money. ${ }^{81}$ Was this annotated volume one of the printers' copies demanded from Basle? There is no evidence on which to decide, but, if it was, Vesalius could well have sent it to Basle around 1560. The sheer expense of publishing a new edition would have deterred Oporinus from

\footnotetext{
77 Colombo, op. cit. (note 49), 216-7; Vesalus, Examen, 47-8; C. Donald O’Malley, 'Gabrielle Fallopia's account of the orbital muscle', in Lloyd G. Stevenson and Robert P. Multhauf (eds), Medicine, Science and Culture. Historical Essays in Honor of Owsei Temkin (Baltimore: Johns Hopkins Press, 1968), 76-85.

78 Vesalius, ibid., 24.

${ }^{79}$ And particularly if he had a second and complete copy, above, p. . Given the on-going difficulties in the Netherlands, he may also have assumed that Philip II's stay in Madrid was only temporary.

${ }^{80}$ Steinmann, op. cit. (note 11), 113, noting the straitened circumstances of Oporinus' last years.

${ }^{81}$ Carlos Gilly, Die Manuskripte in der Bibliothek des Johannes Oporinus (Basle: Schwabe, 2001), 13 (note 14). The sum of 2582 Gulden, possibly loaned by Vesalius, was higher than most other repayments made by Oporinus in his last years, see Steinmann, op. cit. (note 11), 113. Cf. also O'Malley, op. cit. (note 2), 270, for the costs of publishing the second edition.
} 
going ahead immediately, especially if the previous edition had not sold out, and the death first of Vesalius and then of Oporinus would have aborted the whole project.

\section{Conclusion}

These recently discovered annotations, whether ended in 1559 or, less likely, with Vesalius' death in 1564, are the blueprint for a monument that was never built, a third revised edition of the Fabrica. They offer a new insight into the mind of the greatest anatomist of his day. They show a remarkable concern for detail and a willingness to correct the smallest of minutiae. This overwhelming passion for accuracy can be found both in the revisions for the 1555 Fabrica, whose extent is only now being fully appreciated, and in the Norman copy of the reworking of Guinther's Institutiones. But the 1555 Fabrica is the finished work, not the rough scaffolding, while the Norman copy is not available for study, although enough is known to confirm that Vesalius was as precise in his youth as he was twenty or so years later. ${ }^{82}$ These notes, in their wording and in the, at times, confusing handwriting, show Vesalius at work, correcting errors and struggling to find the right words to present his message. Not every page is covered in writing, but few do not have some mark or other made when Vesalius read through this enormous volume. The effort required is visible throughout the book.

The annotations show three sides of Vesalius. There is Vesalius the anatomist, not so much here presenting new anatomical knowledge as ensuring that those who read the book, and who wished to undertake dissection themselves, should not fall into error. Many of the changes are designed to help the dissector by making Vesalius' instructions and example ever clearer. Vesalius thinks as an anatomist; he views the act of dissection as something that requires extraordinary care and precision if it is to be represented on the printed page. The body is something palpable and cannot easily be captured in words.

Then there is Vesalius the humanist, trained from schooldays to write the best Latin. His annotations correct mistakes of grammar and syntax (and new mistakes in hurriedly written notes are almost non-existent), and change words and phrases either for clarity or to impress with their humanist learning. Vesalius' Latin is not that of Cicero or Celsus. It is at times ornate, even stately, in a way that few contemporaries could match. It is not a style easily suited to exposition of complex technical details, but it would have impressed Latinists of the day, and perhaps even an Emperor or two.

Finally, there is Vesalius the artist. The Fabrica, as more than one scholar has noted, achieves the remarkable feat of uniting words and pictures in a complex dialogue. His designers and block-cutters achieved beautiful images that both delight the eye and inform the seeker after truths of the body. But behind them stands Vesalius, whose appreciation of the possibilities of images has been seen as changing contemporary conceptions of understanding. ${ }^{83}$ His readiness to exploit the power of the printing press is well known, as is his ability in his lectures to convey his message through his own drawings. In these notes Vesalius attends to his images just as he does to his words. A mistake by a cutter is corrected as he would do a dropped consonant or vowel. His eye seeks out the misshapen

\footnotetext{
${ }^{82}$ See the description in the Sale Catalogue, op. cit. (note 24).

83 This is the message of Kusukawa's Picturing the Book, op. cit.(note 4), as well as of Martin Kemp, “'The mark of truth": looking and learning in some anatomical illustrations from the renaissance and eighteenth century', in William F. Bynum and Roy Porter (eds), Medicine and the Five Senses (Cambridge: Cambridge University Press, 1991), 85-121.
} 
or illegible letter in the text and also in the plates, and the correction is made clearly for the benefit of the printer.

Vesalius, as contemporaries agreed, was a brilliant anatomist, and his book changed the whole development of anatomy. These notes, through their precision, their variety and their sheer number, give a small glimpse of the man at work. They allow us to penetrate behind the beautiful printed page, the magnificent illustrations and the brilliance of the dissector to see him revising, rephrasing and reordering his message for posterity. One can follow him as he writes, sometimes hurriedly, and then rewrites; he crosses out and provides guidance for printer and cutter in what is at times a struggle for clarity. This book is his work bench as much as the dissecting table. Above all, the notes show, as nothing else, Vesalius' overriding passion for accuracy in both word and image. The annotator now stands alongside the anatomist. 